\title{
Nutrient supply controls picoplankton community structure during three contrasting seasons in the northwestern Mediterranean Sea
}

\author{
Beatriz Mouriño-Carballido, ${ }^{1, *}$, Elena Hojas ${ }^{1}$, Pedro Cermeño ${ }^{2}$, Paloma Chouciño ${ }^{1}$, \\ Bieito Fernández-Castro' ${ }^{1}$, Mikel Latasa ${ }^{3}$, Emilio Marañón ${ }^{1}$, Xosé Anxelu G. Morán ${ }^{3,4}$, \\ Montserrat Vidal ${ }^{5}$
}

\author{
${ }^{1}$ Departamento de Ecoloxía e Bioloxía Animal, Universidade de Vigo, 36310 Vigo (Ponteverdra), Spain \\ ${ }^{2}$ Instituto de Ciencias del Mar, Consejo Superior de Investigaciones Científicas, Passeig Maritim de la Barceloneta, 37-49, \\ 08003 Barcelona, Spain \\ ${ }^{3}$ Centro Oceanográfico de Xixón, Instituto Español de Oceanografía, Avda. Príncipe de Asturias, 70 bis - 33212 Xixón, Spain \\ ${ }^{4}$ King Abdullah University of Science and Technology (KAUST),
}

Division of Biological and Environmental Sciences and Engineering, Red Sea Research Center, Thuwal 23955-6900, Saudi Arabia

${ }^{5}$ Departament d'Ecologia, Universitat de Barcelona, Av. Diagonal, 643, Edifici Margalef, 08028 Barcelona, Spain

\begin{abstract}
We investigated the influence of ocean mixing and nutrient supply dynamics on picoplankton community composition in the context of Margalef's Mandala (Margalef 1978). Simultaneous measurements of microturbulence, nutrient concentration, and autotrophic and heterotrophic picoplankton properties, were collected during 3 cruises carried out in the northwestern Mediterranean Sea in March (F1), April/May (F2) and September (F3) 2009. The 3 cruises sampled different oceanographic conditions, starting with early stages of the late winter-early spring bloom, followed by the late stage of the bloom, and finally summer stratification. As a result of the variability in vertical diffusivity and the nitrate gradient across the nitracline, nitrate vertical fluxes were higher during F1 $\left(23 \pm 35 \mathrm{mmol} \mathrm{m}^{-2} \mathrm{~d}^{-1}\right)$, compared to F2 $\left(0.4 \pm 0.2 \mathrm{mmol} \mathrm{m}^{-2} \mathrm{~d}^{-1}\right)$ and F3 $(0.09 \pm 0.09 \mathrm{mmol}$ $\mathrm{m}^{-2} \mathrm{~d}^{-1}$ ). Prochlorococcus abundance was low when nitrate supply was high, Synechococcus exhibited the highest abundances at intermediate levels of nitrate supply and highest irradiance during F2, and large and small picoeukaryotic groups increased their abundance under high nutrient supply in F1. No significant relationships between the abundance of high and low nucleic acid heterotrophic bacteria and nitrate supply were found. In agreement with Margalef's model, our results show different responses of picophytoplankton groups to nitrate supply (probably reflecting differences in nutrient uptake abilities), and that the ratio of prokaryotic to picoeukaryotic photoautotrophic biomass decreases with increasing nitrate supply.
\end{abstract}

${ }^{*}$ Corresponding author: bmourino@uvigo.es

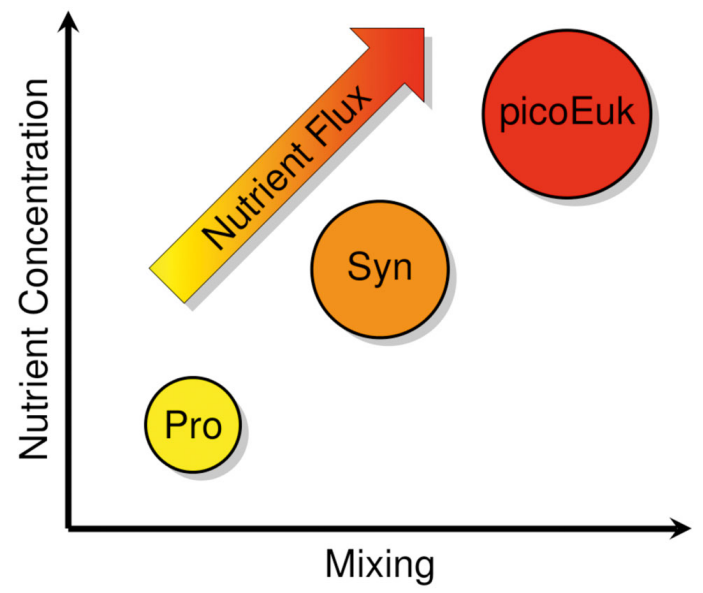

Dominance of Prochlorococcus (Pro), Synechococcus (Syn) and picoeukaryotes (picoEuk) versus turbulent mixing, nutrient concentration and vertical flux of nutrients through turbulent diffusion.

Illustration: Bieito Fernández-Castro

KEY WORDS: . Turbulence $\cdot$ Nutrient supply $\cdot$ Margalef's Mandala $\cdot$ Picoplankton $\cdot$ Mediterranean Sea

\section{INTRODUCTION}

Picoplankton (ca. $<2 \mu \mathrm{m}$ in diameter) are the most abundant organisms in the ocean. They often dominate planktonic biomass and primary production (Chisholm 1992, Marañón 2015), and could represent

() The authors 2016. Open Access under Creative Commons by Attribution Licence. Use, distribution and reproduction are unrestricted. Authors and original publication must be credited. 
a substantial contribution to carbon export (Richardson \& Jackson 2007). The flow cytometric analysis of this planktonic size class allows the discrimination of 2 genera of picocyanobacteria (Synechococcus and Prochlorococcus), usually at least 2 groups of autotrophic picoeukaryotes (small and large), and 2 groups of heterotrophic bacteria according to their high nucleic acid (HNA) or low nucleic acid (LNA) content (Marie et al. 1999). Initially, HNA bacteria were considered as the active fraction and LNA the dormant or dead cells. Although some studies have described similar growth rates for both groups (Longnecker et al. 2005, Scharek \& Latasa 2007), HNA cells usually outgrow LNA cells worldwide (Gasol et al. 1999, Bouvier et al. 2007, Morán et al. 2011).

It would be tempting to treat picophytoplankton as a coherent ecological assemblage; however, this view oversimplifies the large phylogenetic and metabolic diversity shown by their differential spatial distribution. Prochlorococcus is thought to be restricted to water temperatures above $15^{\circ} \mathrm{C}$, extending from the surface to about $150 \mathrm{~m}$ depth in the open ocean between $40^{\circ} \mathrm{N}$ and $40^{\circ} \mathrm{S}$ (Chisholm et al. 1988, Partensky et al. 1999b, Johnson et al. 2006). The vertical distribution of Synechococcus is shallower than that of Prochlorococcus, but covers a wider geographical distribution including both polar and high-nutrient waters (Partensky et al. 1999a, Li 2007, Flombaum et al. 2013). Picoeukaryotes are ubiquitous in surface waters and dominate the picoplankton community along with Synechococcus in coastal systems (Tarran et al. 2006, Schattenhofer et al. 2009, Sharples et al. 2009). These patterns suggest that resource requirements may be important factors regulating the observed regional distribution of picoplankton groups.

Nutrient availability in the surface ocean is determined by nutrient concentration but also by mixing, as was first schematized by Margalef (1978), initially based upon his observations in the Ría de Vigo (northwestern Spain). The original diagram (see Fig. 2 in Margalef 1978) predicts the occurrence of different phytoplankton functional groups versus turbulent mixing ( $x$-axis) and nutrient concentration ( $y$-axis), based on the selection of species-specific functional traits and survival strategies. According to this conceptual model, high turbulence levels and massive and intermittent nutrient inputs favor large-sized phytoplankton, primarily diatoms, that possess high maximum uptake rates and the ability to store nutrients in large, intracellular vacuoles. Conversely, motile species (dinoflagellates) and those with a high affinity for nutrients (coccolithophores) dominate in nutrient-impoverished, stratified systems. The diago- nal between diatoms and dinoflagellates traces the trend in the changing environment and the main sequence from alternative fast-growing $r$-selected to slower growing $K$-selected species (MacArthur \& Wilson 1967, Pianka 1970). If turbulence decays but free nutrients remain abundant, an alternative successional route leads to the species forming harmful algal blooms. High turbulence and low nutrient conditions are too harsh for phytoplankton life, and according to Margalef this domain is empty, meaning that the lifeforms found in such conditions are not adapted to them. A re-orientation of Margalef's first plot was presented a year later to accommodate alternative tracks in the main sequence that might result in red tide formation (Margalef et al. 1979). A recent review of Margalef's model, including a discussion of its dynamic features and significance for blooms, has been provided by Wyatt (2014).

Margalef's model pioneered the use of trait-based approaches in phytoplankton ecology (Litchman 2007). However, several studies carried out in the last decade have noted a number of limitations when applying this approach in the field. First, because Margalef's Mandala was conceived before the discovery of smaller-sized planktonic groups (i.e. picoplankton $<2 \mu \mathrm{m}$ in diameter), it describes only the succession of vegetative phases of microphytoplankton (Wyatt 2014). Moreover, due to the methodological difficulties in quantifying mixing in the field, the validation of Margalef's model has so far been limited to studies where indirect estimates of nutrient supply were used.

In 2009, we conducted simultaneous measurements of microstructure turbulence, nutrient concentration, and picoplankton abundance and cell properties during 3 cruises in the northwestern Mediterranean. Although the Mediterranean Sea is mostly an oligotrophic domain, the northwestern basin is characterized by moderate levels of primary production (Estrada 1996, Morán \& Estrada 2005). In winter, this region is under the influence of strong wind bursts and intense cooling, which generate a deep-mixed patch of dense water, at times extending from the surface down to more than $2000 \mathrm{~m}$ (Leaman \& Schott 1991). Convective mixing and the subsequent late winter-early spring bloom after restratification are responsible for increasing primary production in this region. Our 3 cruises sampled different oceanographic conditions, beginning with early stages of the late winter-early spring bloom, followed by the late stage of the bloom, and ending with summer stratification. Here, we analyze this dataset in order to investigate the response of picoplankton to different levels of mixing and nutrient 
supply, as an attempt to integrate this fundamental group of planktonic microorganisms in the conceptual framework of Margalef's Mandala.

\section{MATERIALS AND METHODS}

Field data were collected during 3 cruises carried out onboard BIO 'Sarmiento de Gamboa' in the northwestern Mediterranean Sea in the framework of the FAMOSO (FAte of the northwestern Mediterranean Open sea Spring blOom) project. The 3 cruises were conducted in 2009, and were designed to cover different stages, starting with the late winter-early spring phytoplankton bloom in FAMOSO-1 (F1: 14 to 22 March), the post-bloom in FAMOSO-2 (F2: 30 April to 13 May) and the late stratification in FAMOSO-3 (F3: 17 to 19 September). During these cruises, conductivity-temperature-depth (CTD) profiles were conducted with a SBE911plus probe (SeaBird Electronics) attached to a rosette equipped with Niskin bottles. Samples were collected from 19 CTD casts for the determination of dissolved inorganic nitrogen and phosphate, as well as picoplankton abundance and cell properties (Table 1, Fig. 1). Wind speed data were collected by the onboard meteorological station. ally, immediately after collection using the procedure of Grasshoff et al. (1999), with a Shimadzu UVprobe spectrophotometer using a $10 \mathrm{~cm}$ cuvette to increase the detection limit to $0.01 \mathrm{mmol} \mathrm{P} \mathrm{m}^{-3}$.

\section{Flow cytometry}

Samples for the determination of picoplankton abundance and cell properties were taken from 5 to 11 depths in the upper $200 \mathrm{~m}$, with higher vertical resolution in the upper $80 \mathrm{~m}$ of the water column. Picoplankton samples $(1.8 \mathrm{ml})$ were preserved with $1 \%$ paraformaldehyde $+0.05 \%$ glutaraldehyde (final concentration). Samples were frozen at $-80^{\circ} \mathrm{C}$ until analysis in the laboratory with a FACSCalibur flow cytometer (Becton-Dickinson) equipped with a laser emitting at $488 \mathrm{~nm}$. To estimate the abundance of the different groups $\left(\right.$ cell $\left.\mathrm{ml}^{-1}\right)$, calibration of the cytometer flow rate was performed daily. Two aliquots from the same sample were used for the study of picophytoplankton $(0.6 \mathrm{ml})$ and heterotrophic bacteria $(0.4$ $\mathrm{ml})$, analyzed at high ( mean $\left.52 \mu \mathrm{l} \mathrm{min}{ }^{-1}\right)$ and low $\left(\sim\right.$ mean $\left.32 \mu \mathrm{l} \mathrm{min}{ }^{-1}\right)$ flow rate, respectively. Before the analysis, the DNA of heterotrophic bacteria was dyed with fluorochrome $2.5 \mu \mathrm{mol} \mathrm{l}^{-1}$ SYTO-13.

Autotrophic cells were separated into 2 groups of cyanobacteria (Synechococcus and Prochlorococcus)

\section{Determination of dissolved inorganic nitrogen and phosphate}

Samples for dissolved inorganic nutrient analysis were collected from 7 to 9 depths in the upper $400 \mathrm{~m}$ and filtered through pre-combusted $\left(450^{\circ} \mathrm{C}\right.$, $4 \mathrm{~h}) 47 \mathrm{~mm}$ diameter Whatman GF/F filters in an acid-cleaned glass filtration system, under low $\mathrm{N}_{2}$-flow pressure. Samples for dissolved inorganic nitrogen (nitrate + nitrite) and phosphate determinations were collected in $30 \mathrm{ml}$ polypropylene and $60 \mathrm{ml}$ polycarbonate bottles, respectively; those for nitrate + nitrite were kept frozen $\left(-20^{\circ} \mathrm{C}\right)$ until analyses. Nitrate + nitrite concentrations (hereafter nitrate) were measured spectrophotometrically with an Alliance Evolution II autoanalyzer following standard procedures (Grasshoff et al. 1999). The detection limit was $0.01 \mathrm{mmol} \mathrm{N} \mathrm{m}^{-3}$. Phosphate concentrations were determined manu-
Table 1. Sampling stations where measurements of microstructure turbulence and cytometry samples were collected during the 2009 FAMOSO cruises (F1: 14 to 22 March; F2: 30 April to 13 May; F3: 17 to 19 September). Column n: number of microturbulence profiles deployed at each station; depth: maximum depth reached by the microturbulence profiler

\begin{tabular}{|lccccccc|}
\hline Cruise & Stn & $\begin{array}{c}\text { Date } \\
(\mathrm{d} / \mathrm{mo} / \mathrm{yr})\end{array}$ & $\begin{array}{c}\text { Time } \\
(\mathrm{GMT})\end{array}$ & $\begin{array}{c}\text { Latitude } \\
\left({ }^{\circ} \mathrm{N}\right)\end{array}$ & $\begin{array}{c}\text { Longitude } \\
\left({ }^{\circ} \mathrm{E}\right)\end{array}$ & $\mathrm{n}$ & $\begin{array}{c}\text { Depth } \\
(\mathrm{m})\end{array}$ \\
\hline F1 & 12 & $14 / 03 / 2009$ & $06: 34: 00$ & 41.583 & 5.095 & 7 & 299 \\
F1 & 16 & $15 / 03 / 2009$ & $12: 56: 00$ & 41.500 & 3.858 & 7 & 257 \\
F1 & 20 & $18 / 03 / 2009$ & $04: 58: 00$ & 41.459 & 4.110 & 7 & 299 \\
F1 & 23 & $19 / 03 / 2009$ & $05: 00: 00$ & 41.618 & 4.176 & 7 & 246 \\
F1 & 26 & $21 / 03 / 2009$ & $06: 11: 00$ & 41.819 & 4.348 & 7 & 287 \\
F1 & 30 & $22 / 03 / 2009$ & $05: 45: 00$ & 41.793 & 4.500 & 7 & 219 \\
F2 & 04 & $30 / 04 / 2009$ & $06: 00: 24$ & 41.500 & 4.874 & 7 & 277 \\
F2 & 10 & $03 / 05 / 2009$ & $04: 56: 44$ & 41.496 & 3.938 & 6 & 276 \\
F2 & 14 & $04 / 05 / 2009$ & $04: 36: 33$ & 41.547 & 3.955 & 7 & 274 \\
F2 & 19 & $07 / 05 / 2009$ & $04: 59: 04$ & 42.106 & 4.475 & 7 & 274 \\
F2 & 25 & $08 / 05 / 2009$ & $04: 52: 48$ & 42.023 & 4.027 & 7 & 277 \\
F2 & 29 & $09 / 05 / 2009$ & $06: 56: 49$ & 42.040 & 4.078 & 7 & 276 \\
F2 & 31 & $10 / 05 / 2009$ & $05: 35: 17$ & 42.057 & 4.155 & 7 & 277 \\
F2 & 35 & $11 / 05 / 2009$ & $05: 29: 39$ & 41.471 & 4.563 & 7 & 278 \\
F2 & 39 & $12 / 05 / 2009$ & $05: 34: 41$ & 41.401 & 4.542 & 7 & 276 \\
F2 & 43 & $13 / 05 / 2009$ & $05: 33: 36$ & 41.352 & 4.507 & 7 & 274 \\
F3 & 07 & $17 / 09 / 2009$ & $04: 20: 17$ & 41.472 & 4.278 & 7 & 299 \\
F3 & 11 & $18 / 09 / 2009$ & $04: 23: 16$ & 41.463 & 4.219 & 7 & 334 \\
F3 & 14 & $19 / 09 / 2009$ & $04: 18: 18$ & 41.928 & 4.032 & 7 & 349 \\
\hline
\end{tabular}




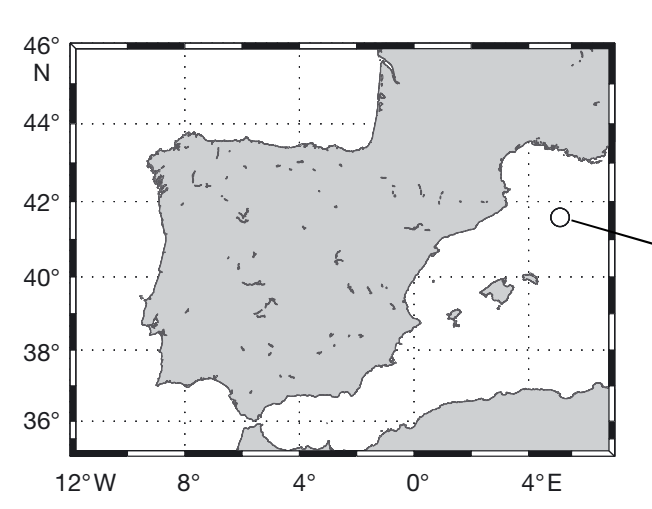

Fig. 1. Area in which microturbulence profiles were conducted during the 2009 FAMOSO cruises (F1: 14 to 22 March, circles; F2: 30 April to 13 May, triangles; F3: 17 to 19 September, squares). Details of the sampling stations are provided in Table 1

and 2 groups of picoeukaryotes (large and small), based on their fluorescence and light scatter signals (SSC), as explained in Calvo-Díaz \& Morán (2006). Two groups of heterotrophic bacteria (HNA and LNA) were distinguished based on their relative green fluorescence (FL1, $530 \mathrm{~nm}$ ), which was used as a proxy for nucleic acid content.

In order to estimate biovolume, we used an empirical calibration between SSC and cell diameter (Calvo-Díaz \& Morán 2006); spherical shape was assumed for all groups. Finally, picoplankton biomass was computed using the following conversion factors of volume to carbon: Norland (1993) for heterotrophic bacteria, $230 \mathrm{fg} \mathrm{C} \mu^{-3}$ for Synechococcus,

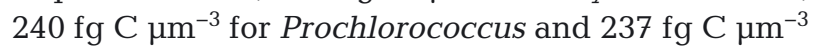
for picoeukaryotes (Worden et al. 2004). More details about the processing and analysis of flow cytometry samples are provided in Gomes et al. (2015).

\section{Measurements of dissipation rates of turbulent kinetic energy and estimates of vertical diffusivity}

Measurements of dissipation rates of turbulent kinetic energy $(\varepsilon)$ were conducted at 19 stations, to a maximum depth of $340 \mathrm{~m}$, using a microstructure profiler (MSS, ISW Wassermesstechnik; Prandke \& Stips 1998) (see Table 1, Fig. 1). Sets of 6 or 7 turbulence profiles were taken at each station. The profiler was equipped with 2 velocity microstructure shear sensors (type PNS98), a microstructure temperature sensor (FPO7), a sensor to measure horizontal acceleration of the profiler and high-precision CTD sen-

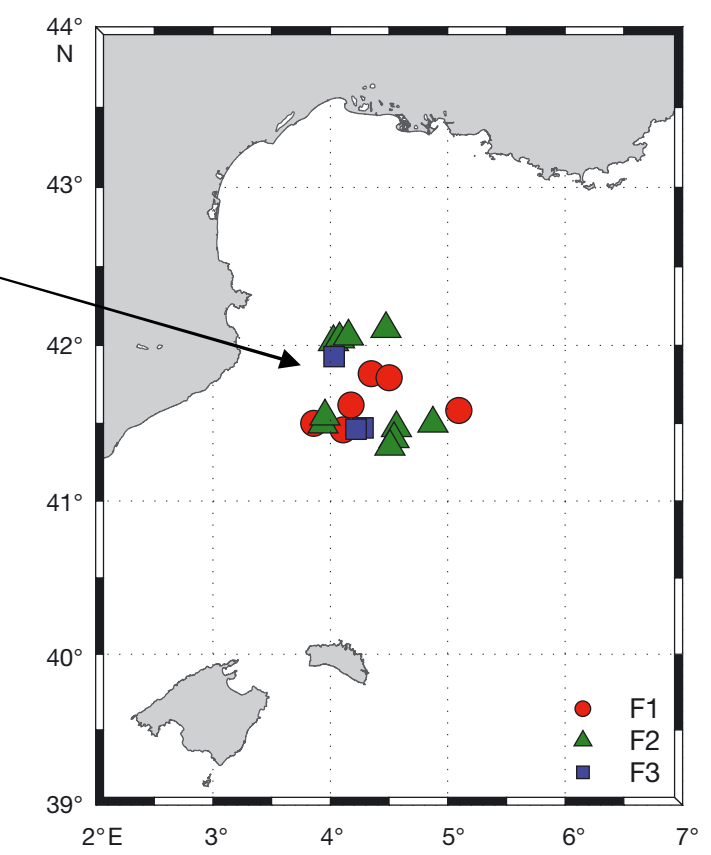

sors. Chlorophyll a (chl a) concentrations between 0.05 and $2.91 \mathrm{mg} \mathrm{m}^{-3}$, fluorometrically determined from water samples collected in the upper $200 \mathrm{~m}$, were used to calibrate the CTD fluorometer $(\mathrm{chl} a=$ $1.8906 \times$ fluorescence $-0.2336 ; \mathrm{R}^{2}=0.71, \mathrm{n}=83$ ). Details of chl a determinations are given in Estrada et al. (2014). The profiler was balanced to have negative buoyancy and a sinking velocity of $\sim 0.4$ to $0.7 \mathrm{~m}$ $\mathrm{s}^{-1}$. The frequency of data sampling was $1024 \mathrm{~Hz}$. The calibration of the shear sensors was performed just before the cruise and the sensitivity was checked daily during data processing. Due to significant turbulence generation close to the ship, data shallower than $10 \mathrm{~m}$ were discarded. The squared BruntVäisälä frequency $\left(N^{2}\right)$, a proxy for water column stratification, was computed from the CTD profiles according to the equation:

$$
N^{2}=-\left(\frac{g}{\rho_{w}}\right)\left(\frac{\partial \rho}{\partial z}\right) \quad\left(\mathrm{s}^{-2}\right)
$$

where $g$ is the acceleration due to gravity $\left(9.8 \mathrm{~m} \mathrm{~s}^{-2}\right)$, $\rho_{W}$ is seawater density $\left(1025 \mathrm{~kg} \mathrm{~m}^{-3}\right)$, and $\partial \rho / \partial z$ is the vertical potential density gradient.

$\varepsilon$ and $N^{2}$ were averaged over depth intervals of $10 \mathrm{~m}$ length. The data processing was carried out with the commercial software MSSpro, which included the removal of spiky data as described in detail in Mouriño-Carballido et al. (2011). Vertical diffusivity $(K z)$ was estimated as:

$$
K z=e \frac{\varepsilon}{N^{2}}
$$

where $e$ is the mixing efficiency, here considered as 0.2 (Osborn 1980), as supported by the comparison of 
microstructure measurements and tracer release experiments both in the open ocean and coastal waters (Ledwell et al. 2000, Oakey \& Greenan 2004, Gregg et al. 2012).

Vertical diffusive fluxes of nitrate were calculated following the Fick's law, from the product of the nitrate gradient across the nitracline and the averaged $K z$ for the same depth interval (Sharples et al. 2001, Fernández-Castro et al. 2015). The nitrate gradient was obtained by linearly fitting nitrate concentrations in the nitracline, determined as the region of approximately maximum and constant gradient, and usually including 3 to 6 nitrate data points.

\section{Light availability}

A Licor photosynthetically active radiation (PAR) sensor placed on the CTD probe was used to obtain vertical profiles of PAR irradiance throughout the water column. The vertical attenuation coefficient was calculated using the Beer-Lambert Law equation (Kirk 1994). Information about daily total solar radiation for each sampling date was obtained from the National Oceanic and Atmospheric Administration (NOAA) database. From these data, daily PAR surface radiation was computed assuming a factor of 0.48 for the contribution of PAR to total radiation (McCree 1972).

Modifying the expression proposed by Vallina \& Simó (2007) for computing solar radiation dose, we calculated a proxy for light availability in the photic layer $(L A)$, considering the magnitude of the surface radiation, the light attenuation coefficient, and the vertical displacements due to turbulent mixing as:

$$
L A=\frac{I_{0}}{k \cdot<L O>_{\mathrm{pl}}}\left(1-\exp ^{-k \cdot<L O>_{\mathrm{pl}}}\right)
$$

where $I_{0}, k$, and $\langle L O\rangle_{\mathrm{pl}}$ are, respectively, surface PAR irradiance, light attenuation coefficient and photic layer (pl) averaged Ozmidov length scale$L O=\left(\varepsilon N^{-3}\right)^{1 / 2}$ - which measures the characteristic length at which stratification-restoring forces roughly balance inertial forces in a turbulent flow (Thorpe 2007), and can be interpreted as the extension of vertical displacements of passive particles or organisms.

\section{Data collected during the TRYNITROP cruise}

In order to determine whether the results derived from the FAMOSO cruises could extend to other regions, we used data from the TRYNITROP cruise, which sampled the tropical and subtropical Atlantic Ocean in April and May 2008. Microstructure turbulence as well as picoplankton abundance and cell properties were measured at a total of 26 stations during this cruise. Microstructure turbulence was determined by using the same microstructure profiler described for the FAMOSO cruises; processing routines for these data and the calculation of nitrate diffusive fluxes were also similar to those described for the FAMOSO cruises (see above). A description of the methodology used during the TRYNITROP cruise for the determination of nitrate concentration is provided in Mouriño-Carballido et al. (2011), and for the analysis of flow cytometry samples in Calvo-Díaz et al. (2011).

\section{RESULTS \\ Hydrographic conditions during the FAMOSO cruises}

The data obtained by the CTD sensors included in the MSS profiler allowed us to characterize the hydrographic conditions during the FAMOSO cruises (Fig. 2). During F1 (14 to 22 March), we sampled the early stages of the late winter-early spring bloom (Estrada et al. 2014), when intense mixing of the water column was observed. The depth of the mixed layer, computed as the depth where sigma-t differs by $0.125 \mathrm{~kg} \mathrm{~m}^{-3}$ from the $10 \mathrm{~m}$ value, extended down to ca. $153 \mathrm{~m}$ at this cruise. Averaged temperature and salinity values at this layer were $13.1^{\circ} \mathrm{C}$ and 38.6, respectively (Table 2). Data collected during F2 (30 April to 13 May) corresponded to the late stage of the spring bloom. Due to the seasonal warming observed at the surface, the mixed layer averaged over this cruise was shallower $(\sim 28 \mathrm{~m})$ and characterized by averaged temperature and salinity values of $15.1^{\circ} \mathrm{C}$ and 38.3 , respectively. The mixed layer was deeper $(\sim 33 \mathrm{~m})$ at the stations sampled during the first part of this cruise (Stns 4 to $25)$, compared with those stations sampled during the second part $(\sim 17 \mathrm{~m}$, Stns 29 to 43). Finally, during F3 (17 to $19 \mathrm{Sep}$ ) we sampled late summer stratification conditions. The mixed layer, which extended down to a depth of $\sim 33 \mathrm{~m}$, was significantly warmer $\left(\sim 23.6^{\circ} \mathrm{C}\right)$ and fresher $(\sim 38.2)$ compared to F1. The relatively higher surface salinity observed during F1 was due to convection of surface waters-which were cool and salty as a result of evaporation associated with the cold and dry Mistral and Tramontana winds (Leaman \& 

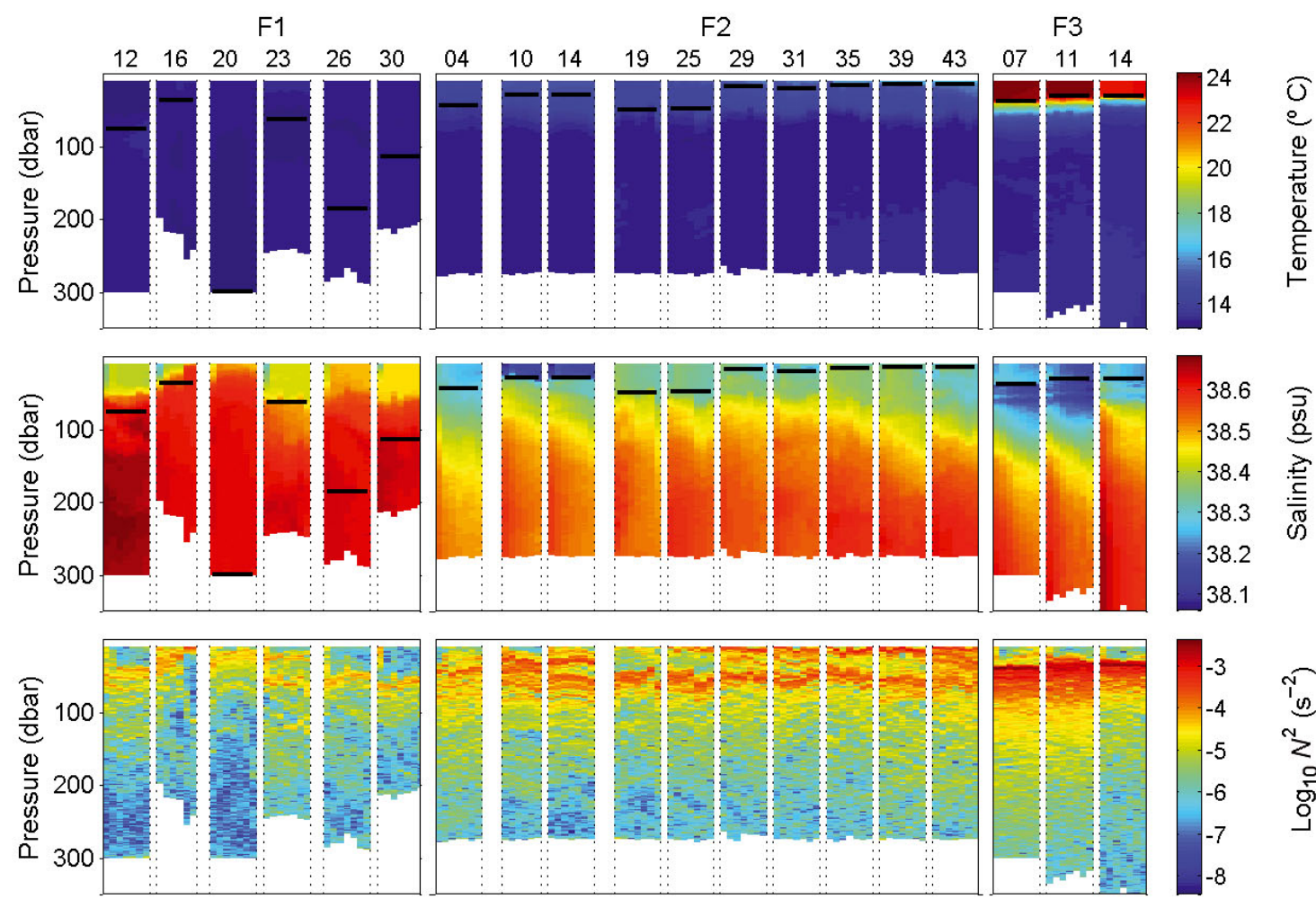

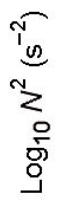
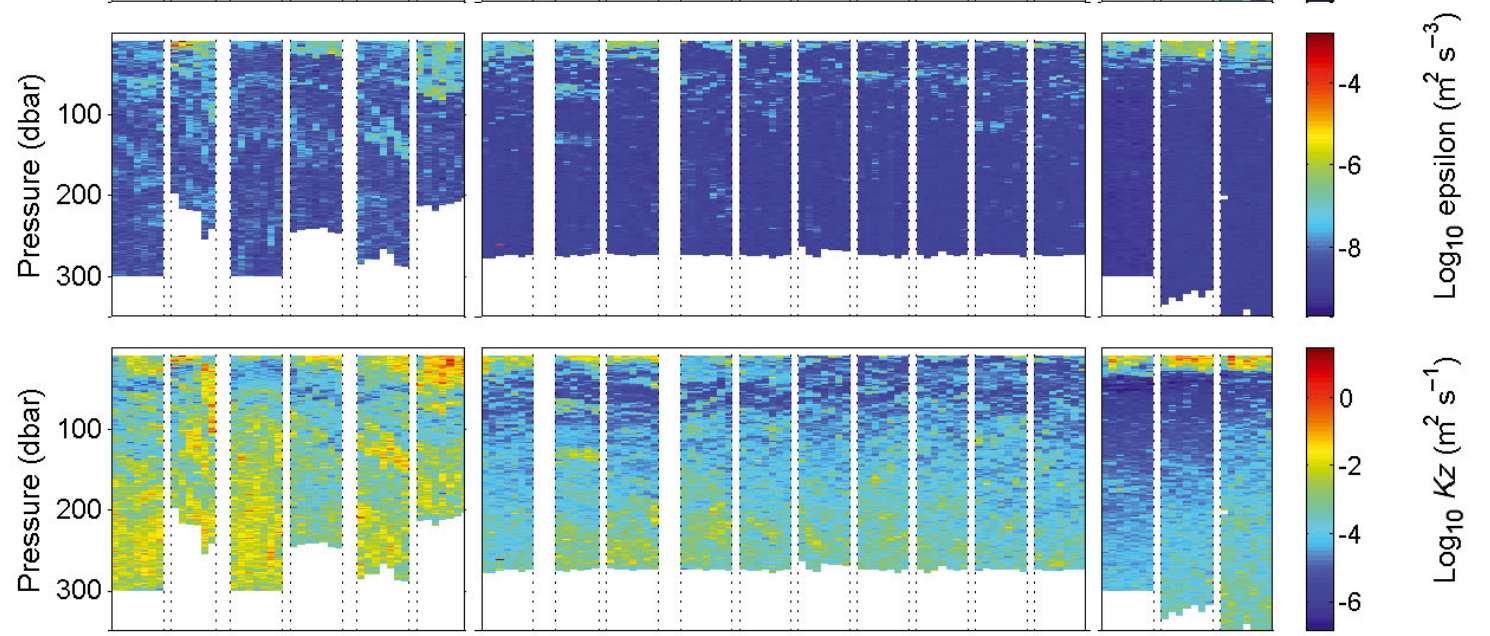

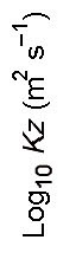

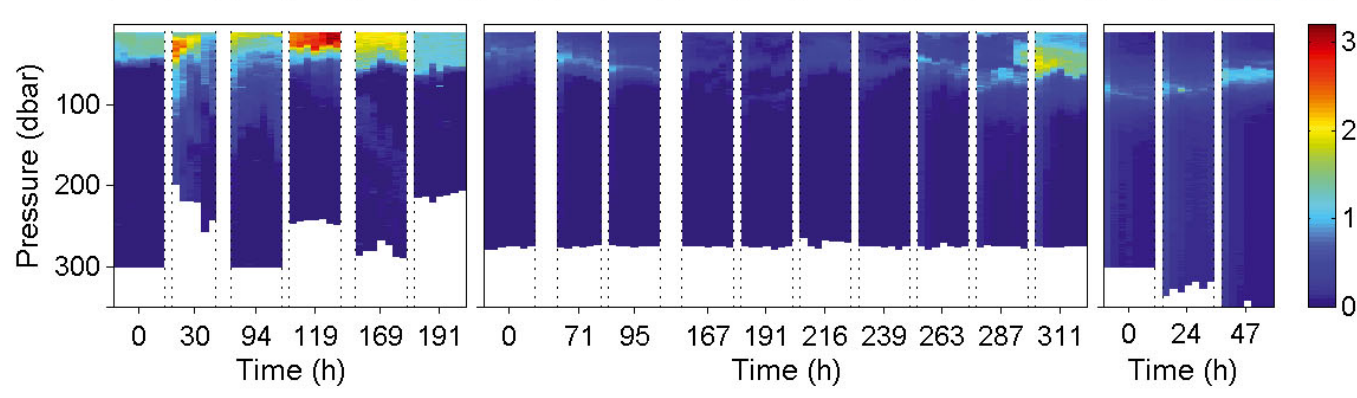

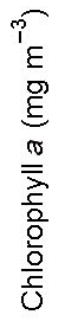

Fig. 2. Vertical distribution of temperature $\left({ }^{\circ} \mathrm{C}\right)$, salinity (psu), Brünt-Väissäla frequency $\left(\mathrm{s}^{-2}\right.$, note the logarithmic transformation), dissipation rates of turbulent kinetic energy $\left(\mathrm{m}^{2} \mathrm{~s}^{-3}\right.$, note the logarithmic transformation), vertical diffusivity $\left(K z, \mathrm{~m}^{2} \mathrm{~s}^{-1}\right.$, note the logarithmic transformation) and $\mathrm{chl} \mathrm{a}\left(\mathrm{mg} \mathrm{m}^{-3}\right)$ measured with the microturbulence profiler during the FAMOSO cruises F1, F2 and F3. Black line: averaged mixed layer depth computed for each station as the depth where sigma-t differs $0.125 \mathrm{~kg} \mathrm{~m}^{-3}$ from the $10 \mathrm{~m}$ value. Numbers at the top indicate station numbers (see Table 1). For each station the 6 or 7 microturbulence profiles deployed are plotted. Time between stations is not proportional to the time scale plotted in the $x$-axis 
Table 2. Mean $( \pm \mathrm{SD})$ values for selected variables collected during FAMOSO cruises F1, F2 and F3; SD was calculated using all profiles deployed at each cruise. $\varepsilon$ : dissipation rate of turbulent kinetic energy; $N^{2}$ : Brunt-Väisälä frequency; $1 \%$ PAR depth: depth of $1 \%$ of the surface photosynthetically active radiation; LA: light availability in the photic layer. Surface values correspond to data collected at ca. $5 \mathrm{~m}$. Nitrate concentrations (abundance and biomass of picoplankton groups) correspond to depth-integrated values for the upper $100 \mathrm{~m}$ (down to the photic layer depth). $\varepsilon, N^{2}$, vertical diffusivity, nitrate gradients and diffusive fluxes were calculated across the nutricline (see 'Materials and methods'). Cell volume: averaged volume computed for the photic layer; LNA: low nucleic acid content bacteria; HNA: high nucleic acid content bacteria; Proch: Prochlorococcus; Syne: Synechococcus; S_picoEuk: small picoeukaryotes; L_picoEuk: large picoeukaryotes. Contribution (\%) of individual groups to total picoplankton biomass is indicated. A nonparametric 1-way ANOVA (Kruskal-Wallis) was performed to test the null hypothesis that independent groups come from distributions with equal medians. The Bonferroni multiple comparison test was applied a posteriori to analyze the differences between every pair of groups $(1=\mathrm{F} 1,2=\mathrm{F} 2$ and $3=\mathrm{F} 3) .{ }^{*} \mathrm{p}<0.05$; ${ }^{* *} \mathrm{p}<0.01 ;{ }^{* * *} \mathrm{p}<0.001$

\begin{tabular}{|c|c|c|c|c|c|}
\hline Variable & F1 & $\mathrm{F} 2$ & F3 & $\begin{array}{c}\text { Kruskal-Wallis } \\
\text { p-value }\end{array}$ & $\begin{array}{c}\text { Bonferroni } \\
\text { comparisons }\end{array}$ \\
\hline Surface temperature $\left({ }^{\circ} \mathrm{C}\right)$ & $13.12 \pm 0.03$ & $15.1 \pm 0.7$ & $23.6 \pm 0.7$ & $<0.001^{* * *}$ & $1<2,3$ \\
\hline Surface salinity & $38.59 \pm 0.02$ & $38.30 \pm 0.06$ & $38.24 \pm 0.03$ & $0.002^{* *}$ & $1>2,3$ \\
\hline Mixed layer depth (m) & $153 \pm 105$ & $28 \pm 14$ & $33 \pm 4$ & $<0.001^{* * *}$ & $1<2,3$ \\
\hline$N^{2}\left(\mathrm{~s}^{-2}\right) \times 10^{-5}$ & $1.7 \pm 2.7$ & $7.0 \pm 8.6$ & $16.0 \pm 1.9$ & $<0.001^{* * *}$ & $1<2<3$ \\
\hline$\varepsilon\left(\mathrm{m}^{2} \mathrm{~s}^{-3}\right) \times 10^{-8}$ & $155 \pm 4345$ & $1.2 \pm 4.6$ & $0.4 \pm 1.7$ & $<0.001^{* * *}$ & $1>2>3$ \\
\hline Vertical diffusivity $\left(\mathrm{m}^{2} \mathrm{~s}^{-1}\right) \times 10^{-4}$ & $70.7 \pm 241.9$ & $0.56 \pm 0.94$ & $0.087 \pm 0.098$ & $<0.001^{* * *}$ & $1>2>3$ \\
\hline Nitrate $(0-100 \mathrm{~m})\left(\mathrm{mmol} \mathrm{m}^{-2}\right)$ & $207 \pm 41$ & $186 \pm 23$ & $161 \pm 21$ & 0.057 & \\
\hline Surface nitrate $\left(\mathrm{mmol} \mathrm{m}^{-3}\right)$ & $4.5 \pm 1.3$ & $1.7 \pm 0.6$ & $1.3 \pm 0.4$ & $0.002^{* *}$ & $1>2,3$ \\
\hline Nitrate gradient $\left(\mu \mathrm{mol} \mathrm{m}{ }^{-4}\right)$ & $81 \pm 49$ & $94 \pm 31$ & $124 \pm 4$ & 0.144 & \\
\hline Nitrate flux (mmol m$\left.{ }^{-2} \mathrm{~d}^{-1}\right)$ & $23 \pm 35$ & $0.4 \pm 0.2$ & $0.09 \pm 0.09$ & $<0.001^{* * *}$ & $1>2,3$ \\
\hline $1 \%$ PAR depth $(\mathrm{m})$ & $47 \pm 5$ & $67 \pm 7$ & $75 \pm 12$ & $0.004^{* *}$ & $1<2,3$ \\
\hline Surface PAR $\left(\mu \mathrm{mol}\right.$ photons $\left.\mathrm{m}^{-2} \mathrm{~s}^{-1}\right)$ & $493 \pm 42$ & $625 \pm 92$ & $411 \pm 72$ & $0.004^{* *}$ & $2>3$ \\
\hline LA $\left(\mu \mathrm{mol}\right.$ photons $\left.\mathrm{m}^{-2} \mathrm{~s}^{-1}\right)$ & $372 \pm 115$ & $613 \pm 87$ & $379 \pm 77$ & $0.004^{* *}$ & $1<2>3$ \\
\hline Surface chlorophyll a $\left(\mathrm{mg} \mathrm{m}^{-3}\right)$ & $1.7 \pm 0.5$ & $0.5 \pm 0.3$ & $0.2 \pm 0.1$ & $<0.001^{* * *}$ & $1>2>3$ \\
\hline LNA abundance $\left(\right.$ cells m $\left.{ }^{-2}\right) \times 10^{13}$ & $1.64 \pm 0.58$ & $2.39 \pm 1.33$ & $2.42 \pm 0.55$ & 0.216 & \\
\hline HNA abundance $\left.(\text { cells m})^{-2}\right) \times 10^{13}$ & $2.39 \pm 1.31$ & $1.66 \pm 0.80$ & $2.07 \pm 0.71$ & 0.420 & \\
\hline Proch abundance $\left(\right.$ cells m $\left.\mathrm{m}^{-2}\right) \times 10^{11}$ & $0.72 \pm 0.23$ & & $52.87 \pm 24.85$ & $0.020^{*}$ & $1<3$ \\
\hline Syne abundance $\left(\right.$ cells $\left.\mathrm{m}^{-2}\right) \times 10^{11}$ & $26.01 \pm 10.56$ & $74.15 \pm 50.18$ & $9.10 \pm 3.52$ & $0.004^{* *}$ & $2>3$ \\
\hline S_picoEuk abundance $\left(\right.$ cells m $\left.{ }^{-2}\right) \times 10^{11}$ & $5.67 \pm 1.82$ & $1.54 \pm 0.51$ & $0.49 \pm 0.40$ & $<0.001^{* * *}$ & $1>2,3$ \\
\hline $\mathrm{L} \_$picoEuK abundance $\left(\right.$cells m $\left.{ }^{-2}\right) \times 10^{11}$ & $1.90 \pm 0.60$ & $0.48 \pm 0.49$ & $0.66 \pm 0.41$ & $0.008^{* *}$ & $1>2$ \\
\hline LNA cell volume $\left(\mu \mathrm{m}^{3}\right.$ cell $\left.^{-1}\right)$ & $0.054 \pm 0.003$ & $0.046 \pm 0.005$ & $0.046 \pm 0.003$ & $0.017^{*}$ & $1>2$ \\
\hline HNA cell volume $\left(\mu^{3}\right.$ cell $\left.^{-1}\right)$ & $0.045 \pm 0.003$ & $0.059 \pm 0.011$ & $0.059 \pm 0.013$ & $0.003^{* *}$ & $1<2,3$ \\
\hline Proch cell volume $\left(\mu \mathrm{m}^{3} \mathrm{cell}^{-1}\right)$ & $0.16 \pm 0.02$ & & $0.3 \pm 0.2$ & $0.020^{*}$ & $1<3$ \\
\hline Syne cell volume $\left(\mu \mathrm{m}^{3}\right.$ cell $\left.^{-1}\right)$ & $0.52 \pm 0.04$ & $0.58 \pm 0.11$ & $0.67 \pm 0.10$ & $0.006^{* *}$ & $1<3$ \\
\hline S_picoEuk cell volume $\left(\mu^{3}{ }^{3}\right.$ cell $\left.^{-1}\right)$ & $1.30 \pm 0.16$ & $1.79 \pm 0.29$ & $1.78 \pm 0.34$ & $0.003^{* *}$ & $1<2$ \\
\hline L_picoEuK cell volume $\left(\mu \mathrm{m}^{3} \mathrm{cell}^{-1}\right)$ & $3.6 \pm 0.5$ & $4.9 \pm 1.6$ & $3.90 \pm 0.78$ & $0.011^{*}$ & $1<2$ \\
\hline HNA biomass $\left(\mathrm{mg} \mathrm{C} \mathrm{m}^{-2}\right)$ & $302 \pm 166$ & $256 \pm 146$ & $328 \pm 58$ & 0.623 & \\
\hline LNA biomass ( $\mathrm{mg} \mathrm{C} \mathrm{m}^{-2}$ ) & $270 \pm 156$ & $316 \pm 196$ & $276 \pm 38$ & 0.826 & \\
\hline Proch biomass (mg C m${ }^{-2}$ ) & $3 \pm 1$ & & $216 \pm 12$ & $0.020^{*}$ & $1<3$ \\
\hline Syne biomass $\left(\mathrm{mg} \mathrm{C} \mathrm{m}^{-2}\right)$ & $325 \pm 114$ & $871 \pm 570$ & $134 \pm 57$ & $0.002^{* *}$ & $2>3$ \\
\hline S_picoEuk biomass $\left(\mathrm{mg} \mathrm{C} \mathrm{m}^{-2}\right)$ & $171 \pm 48$ & $63 \pm 18$ & $20 \pm 14$ & $<0.001^{* * *}$ & $1>2,3$ \\
\hline L_picoEuk biomass $\left(\mathrm{mg} \mathrm{C} \mathrm{m}^{-2}\right)$ & $167 \pm 52$ & $64 \pm 75$ & $50 \pm 21$ & $0.019^{*}$ & $1>2$ \\
\hline HNA biomass $(\%)$ & $23 \pm 7$ & $16 \pm 7$ & $32 \pm 3$ & $0.011^{*}$ & $2<3$ \\
\hline LNA biomass (\%) & $21 \pm 6$ & $20 \pm 8$ & $27 \pm 3$ & 0.215 & \\
\hline Proch biomass (\%) & $0.3 \pm 0.1$ & & $21 \pm 3$ & $<0.001^{* * *}$ & $1<3$ \\
\hline Syne biomass (\%) & $24 \pm 4$ & $51 \pm 18$ & $11 \pm 5$ & $0.004^{* *}$ & $2>3$ \\
\hline S_picoEuk biomass (\%) & $14 \pm 4$ & $4 \pm 4$ & $2 \pm 1$ & $<0.001^{* *}$ & $1>2,3$ \\
\hline L picoEuK biomass ( $\%$ ) & $13+3$ & $4+3$ & $5+2$ & $0.003^{* *}$ & $1>2$ \\
\hline
\end{tabular}

Schott 1991)-leading to mixing with deeper salty waters from the Levantine Intermediate Water mass.

The vertical distribution of $N^{2}$ indicated a progressive increase of the surface stratification from F1 to F3. Averaged $N^{2}$ values computed for the nutricline were about $1.7 \times 10^{-5} \mathrm{~s}^{-2}$ in F1, $7 \times 10^{-5} \mathrm{~s}^{-2}$ in F2 and $16 \times 10^{-5} \mathrm{~s}^{-2}$ in F3 (Table 2). As a consequence of local meteorological forcing in the form of wind stress and buoyancy fluxes (Moum \& Smyth 2001), $\varepsilon$ exhibited higher values close to the surface (Fig. 3). Parallel to the progressive warming and stratification of the surface layers, averaged values of $\varepsilon$ for the nutricline decreased from F1 $\left(\sim 155 \times 10^{-8} \mathrm{~m}^{2} \mathrm{~s}^{-3}\right)$ to $\mathrm{F} 2$ and F3 $\left(\sim 1.2 \times 10^{-8}\right.$ and $0.4 \times 10^{-8} \mathrm{~m}^{2} \mathrm{~s}^{-3}$, respectively) 
Because $K z$ is determined by the distributions of $\varepsilon$ and $N^{2}$ (see 'Materials and methods'), lower values of $K z$ were observed where vertical stratification was maximum. Averaged $K z$ values for the nutricline were higher at F1 $\left(\sim 70.7 \times 10^{-4} \mathrm{~m}^{2} \mathrm{~s}^{-1}\right)$ compared to F2 $\left(\sim 0.56 \times 10^{-4} \mathrm{~m}^{2} \mathrm{~s}^{-1}\right)$ and F3 $\left(\sim 0.087 \times 10^{-4} \mathrm{~m}^{2} \mathrm{~s}^{-1}\right)$ (Table 2).

Chl a concentration was higher during F1, when maximum values were located at the surface $(1.7 \pm$ $0.5 \mathrm{mg} \mathrm{m}^{-3}$; Table 2). In comparison to F1, maximum values of chl a during F2 $\left(0.5 \pm 0.3 \mathrm{mg} \mathrm{m}^{-3}\right)$ and F3 $\left(0.2 \pm 0.1 \mathrm{mg} \mathrm{m}^{-3}\right)$ were lower and deeper $(\sim 50 \mathrm{~m}$ in $\mathrm{F} 2$ and 60 to $80 \mathrm{~m}$ in F3). Although seasonal changes were clear between cruises, important variability was observed between stations sampled during each cruise, and between profiles sampled at each station. For example, during F2, Stns 19 and 25 were characterized by relatively low values of chlorophyll, whereas higher values were measured at Stns 39 and 43. This variability was probably linked to the intense mesoscale and submesoscale activity occurring in the region, which was responsible for the important within-cruise variability observed in several physical, chemical and biological properties during this cruise (Estrada et al. 2014).

As a result of the progressive increase in stratification and biological uptake (Estrada et al. 2014), surface nitrate concentration decreased from F1 (4.5 $\left.\pm 1.3 \mathrm{mmol} \mathrm{N} \mathrm{m}^{-3}\right)$ to $\mathrm{F} 2\left(1.7 \pm 0.6 \mathrm{mmol} \mathrm{N} \mathrm{m}^{-3}\right)$ and F3 $\left(1.3 \pm 0.4 \mathrm{mmol} \mathrm{N} \mathrm{m}^{-3}\right)$ (Table 2$)$, with similar patterns observed for phosphate concentration (Fig. 3). Despite the observed within-cruise variability, differences in key physical, chemical and biological variables between cruises are clear when observing the averaged profiles (Fig. 4).
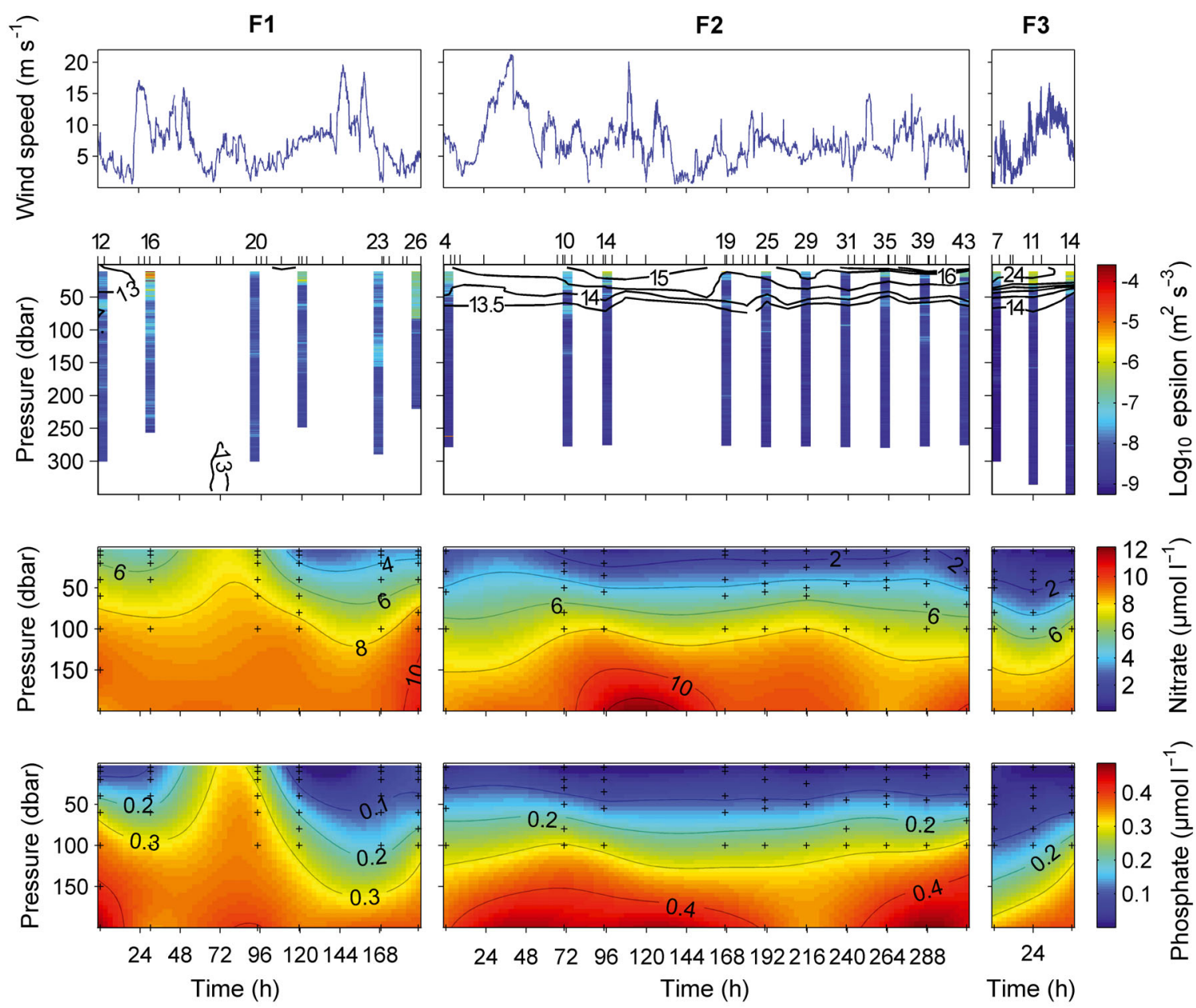

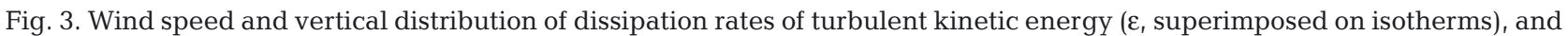
nitrate and phosphate concentration sampled during the FAMOSO cruises F1, F2 and F3. Numbers at the top indicate station numbers (see Table 1) and ticks indicate all CTD casts deployed at each cruise. Epsilon profiles correspond to averaged values computed from the 6 or 7 profiles deployed at each station 


\section{Picoplankton community composition and cell properties}

In general, higher abundances of picoplankton groups were observed at the surface, except for heterotrophic bacteria during F2 (maximum abundance located at ca. 50 to $80 \mathrm{~m}$ at Stn 43), and autotrophic picoplankton during F3, when maxima were occasionally located at 50 to $80 \mathrm{~m}$, just above the deep chlorophyll maximum (Fig. 5). Surface LNA bacteria abundance ranged from $<2 \times 10^{5}$ cells ml $^{-1}$ during F2 (Stns 29,31 and 35) to $>6 \times 10^{5} \mathrm{cells} \mathrm{ml}^{-1}$ during F1 (Stns 26 and 30). Surface HNA bacterial abundance was also lowest during F2 (Stns 25 to $35,<2.5 \times 10^{5}$ cells ml $^{-1}$ ) and highest during F1 (Stns 26 and 30,>10 $\times 10^{5}$ cells $\mathrm{ml}^{-1}$ ). LNA bacteria were generally more abundant than HNA, except during F1. Averaged depth-integrated abundance for these 2 groups did not differ statistically between cruises, and ranged ca. 1.6 to $2.4 \times 10^{13}$ cells $\mathrm{m}^{-2}$ (Table 2). Prochlorococcus showed low abundance during F1 $\left(<0.5 \times 10^{4}\right.$ cells $\mathrm{ml}^{-1}$ ), was absent during $\mathrm{F} 2$ and showed relatively high abundance during F3, when a maximum cell density of ca. $1.9 \times 10^{5}$ cells ml $^{-1}$ was found at $50 \mathrm{~m}$ at
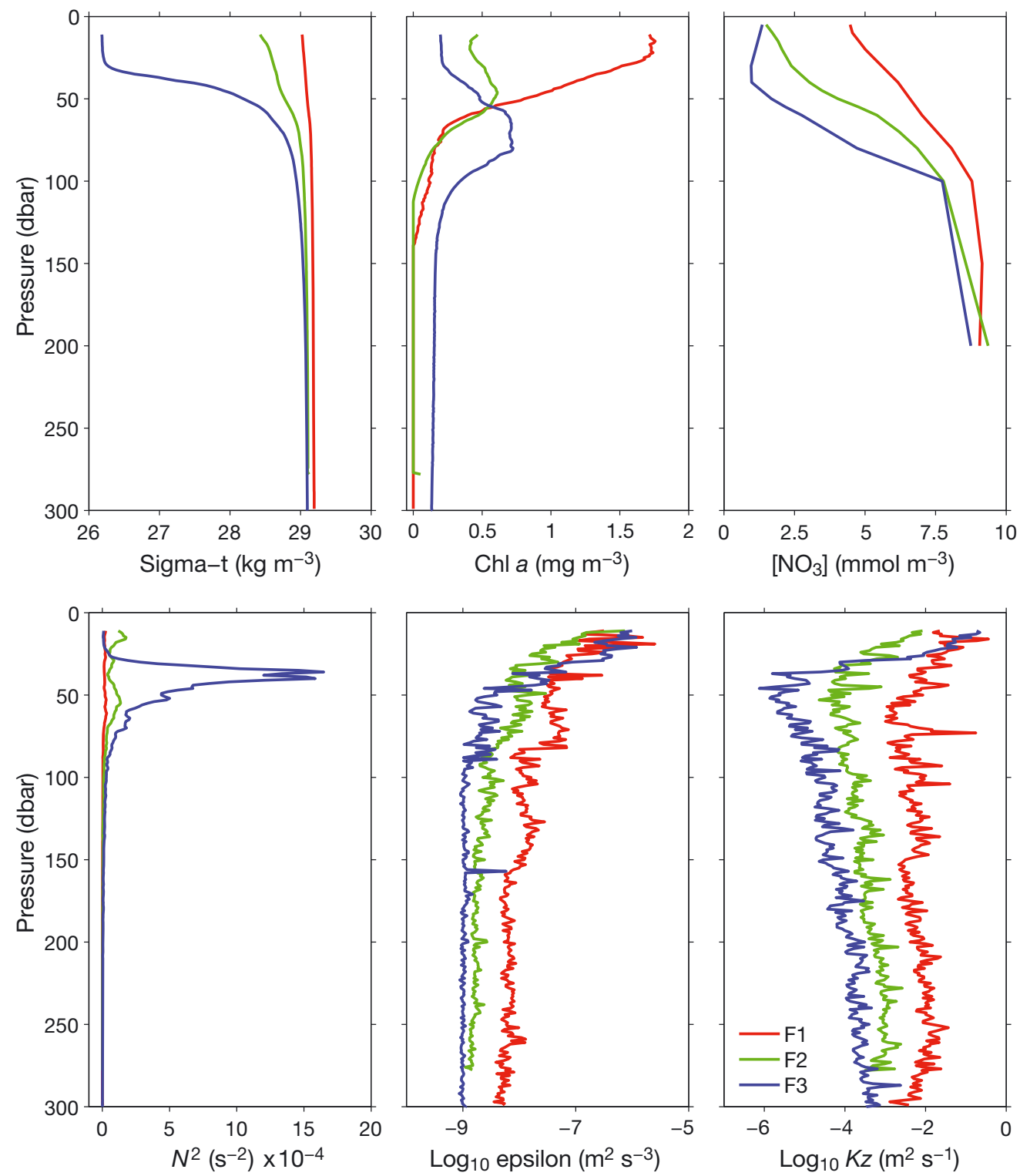

Fig. 4. Averaged vertical distribution of sigma-t, chl $a$, nitrate concentration, Brünt-Väissäla frequency, dissipation rates of turbulent kinetic energy ( $\varepsilon$, note the logarithmic transformation), and vertical diffusivity ( $K z$, note the logarithmic transformation) measured with the microturbulence profiler during the FAMOSO cruises F1, F2 and F3 

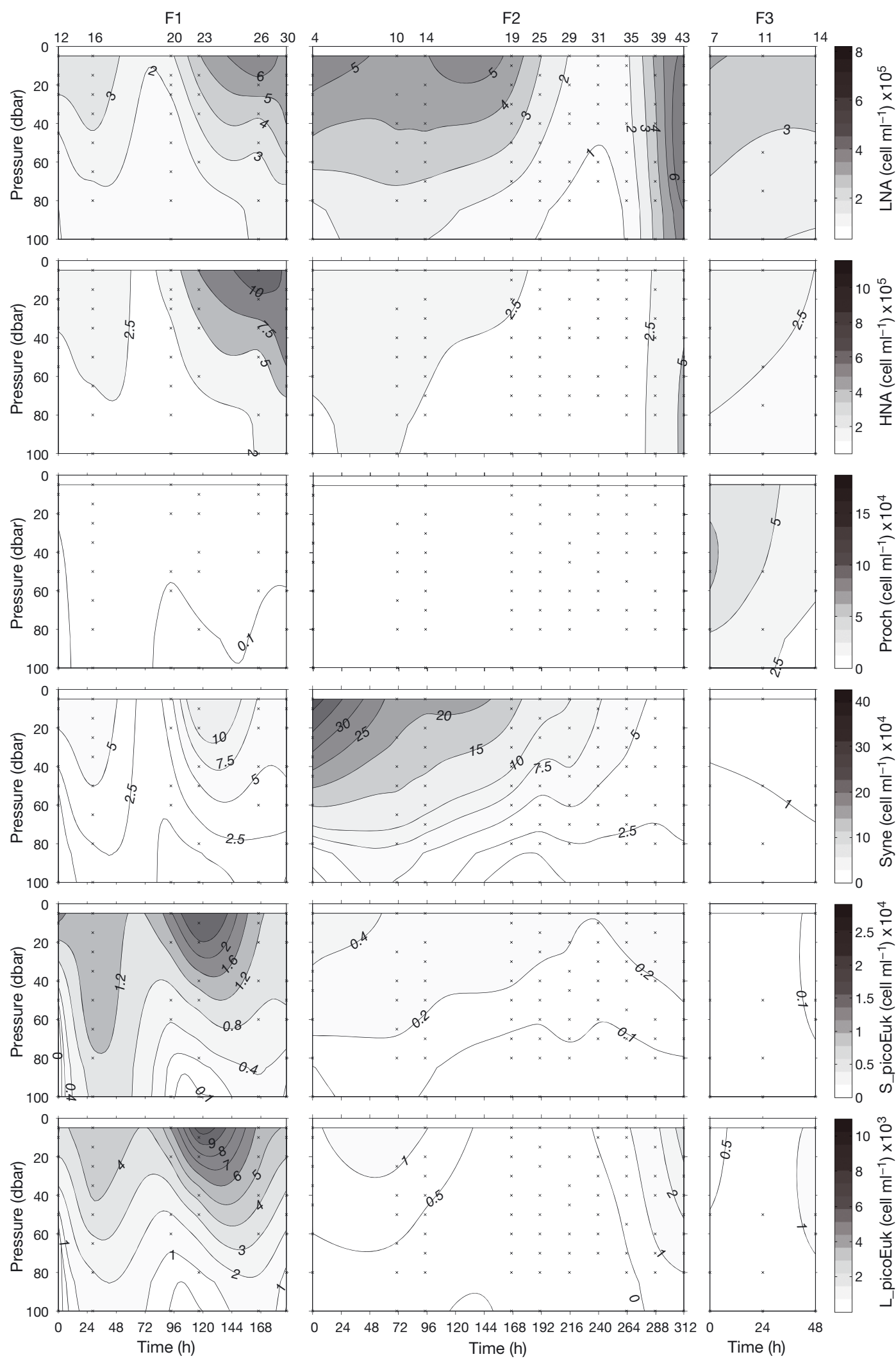

Fig. 5. Vertical distribution of the abundance (cell $\mathrm{ml}^{-1}$ ) of low nucleic acid content bacteria (LNA), high nucleic acid content bacteria (HNA), Prochlorococcus, Synechococcus, small picoeukaryotes and large picoeukaryotes during the FAMOSO cruises F1, F2 and F3. Numbers at the top indicate station numbers (see Table 1) 
Stn 7. Averaged depth-integrated abundance was significantly higher during F3 $\left(53 \pm 25 \times 10^{11}\right.$ cells $\left.\mathrm{m}^{-2}\right)$ compared to F1 $\left(0.7 \pm 0.2 \times 10^{11}\right.$ cells m$\left.{ }^{-2}\right)$ (Table 2). Surface Synechococcus abundance ranged from 1.6 to $37 \times 10^{4} \mathrm{cells} \mathrm{ml}^{-1}$. The lowest values were found during F3, whereas the highest abundance was sampled during F2 (Stn 4). Averaged depthintegrated abundance for this group was only statistically higher during F2 $\left(74 \pm 50 \times 10^{11}\right.$ cells m$\left.^{-2}\right)$ compared to F3 $\left(9 \pm 4 \times 10^{11}\right.$ cells m$\left.^{-2}\right)$ (Table 2). Finally, the abundance of small and large picoeukaryotes exhibited very similar distributions. Their abundance was higher during F1, when peak values of $2.9 \times 10^{4}$ cells ml ${ }^{-1}$ (small) and $1 \times 10^{4}$ cells ml ${ }^{-1}$ (large) were measured at the surface at Stn 23. During F2 and F3, the abundance of small and large picoeukaryotes was lower than $0.5 \times 10^{4}$ cells ml ${ }^{-1}$ and $4 \times 10^{3}$ cells $\mathrm{ml}^{-1}$, respectively. Averaged depth-integrated abundance of small picoeukaryotes was statistically higher during F1 $\left(6 \pm 2 \times 10^{11}\right.$ cells m$\left.^{-2}\right)$ compared to F2 $\left(1.5 \pm 0.5 \times 10^{11}\right.$ cells m$\left.^{-2}\right)$ and F3 $\left(0.5 \pm 0.4 \times 10^{11}\right.$ cells $\mathrm{m}^{-2}$ ). For the larger picoeukaryote group, statistical analysis only showed significant differences between F1 $\left(1.9 \pm 0.6 \times 10^{11}\right.$ cells m$\left.^{-2}\right)$ and F2 $(0.5 \pm$ $0.5 \times 10^{11}$ cells m$^{-2}$ ) (Table 2).

It is remarkable that LNA $\left(0.054 \pm 0.003 \mu^{3}\right)$ were larger than HNA $\left(0.045 \pm 0.003 \mu^{3}\right)$ bacteria during F1 (Table 2) (Gomes et al. 2015), whereas the opposite trend, frequently observed in temperate waters (Calvo-Díaz \& Morán 2006), was observed during F2 and F3. LNA bacteria were larger during F1 compared to F2, whereas the opposite trend was found for HNA bacteria. Prochlorococcus cells were smaller during F1 compared to F3. During F1, Synechococcus and small picoeukaryotes were also smaller compared to both F2 and F3. Large picoeukaryotes were smaller during F1 compared to F2.

Combining the information of abundance and cell size, we determined the contribution of each group to the picoplankton total carbon biomass (Table 2, Fig. 6). Due to the variability observed between the stations sampled during the same cruise, LNA and HNA bacterial biomass did not differ statistically between the 3 periods. Prochlorococcus biomass was higher during F3 $\left(216 \pm 12 \mathrm{mg} \mathrm{C} \mathrm{m}^{-2}\right)$ compared to F1 $\left(3 \pm 1 \mathrm{mg} \mathrm{C} \mathrm{m}^{-2}\right)$, whereas an increase in Synechococcus biomass was observed during F2 $(871 \pm 570 \mathrm{mg}$ $\left.\mathrm{C} \mathrm{m}^{-2}\right)$, compared to F1 $\left(325 \pm 114 \mathrm{mg} \mathrm{C} \mathrm{m}^{-2}\right)$ and F3 $\left(134 \pm 57 \mathrm{mg} \mathrm{C} \mathrm{m}^{-2}\right)$. Finally, small $\left(171 \pm 48 \mathrm{mg} \mathrm{C} \mathrm{m}^{-2}\right)$ and large $\left(167 \pm 52 \mathrm{mg} \mathrm{C} \mathrm{m}^{-2}\right)$ picoeukaryote biomass was higher during F1 compared to F3 $(20 \pm 14$ and $50 \pm 21 \mathrm{mg} \mathrm{C} \mathrm{m}^{-2}$, respectively) (Table 2).

Heterotrophic bacteria were the main contributors to carbon picoplankton biomass except during F2, when the contribution of Synechococcus significantly increased up to $51 \%$ (Table 2, Fig. 6). Prochlorococcus biomass contributed $<1 \%$ during F1 and increased up to $21 \%$ in F3. Finally, the contribution of small and large picoeukaryotes decreased from F1 (13 to $14 \%$ ) to F3 (2 to $5 \%)$.

\section{Correlations between nitrate fluxes and the picoplankton community}

The magnitude of nitrate fluxes were the result of the mixing conditions and the vertical nitrate gradient across the nitracline. Mixing conditions,
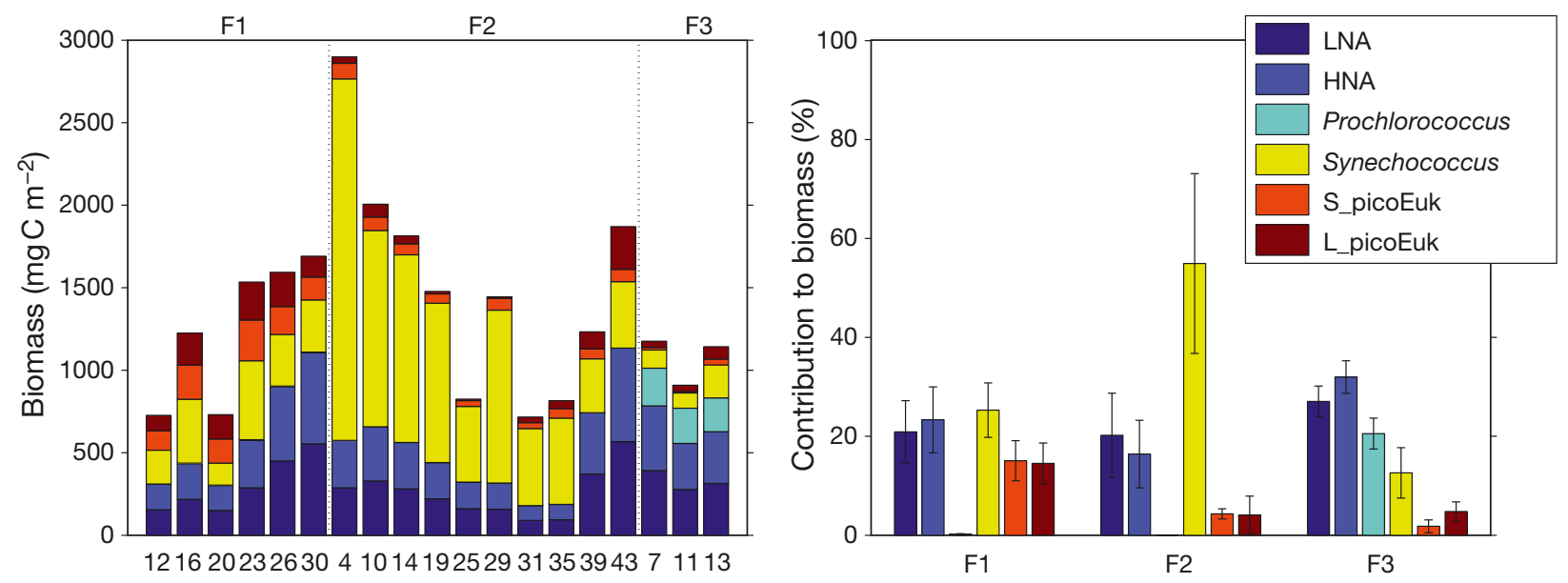

Fig. 6. Photic layer depth-integrated biomass (left) and averaged contribution to total picoplankton biomass (right) of low and high nucleic acid content bacteria (LNA and HNA), Prochlorococcus, Synechococcus, small and large picoeukaryotes during the FAMOSO cruises F1, F2 and F3. Numbers at the bottom in the left panel indicate station numbers (see Table 1); error bars: SD 
represented by the value of vertical diffusivity, were higher during F1 compared to F2 and F3 (Table 2, Fig. 2). As a consequence of the increase in stratification, the nitrate gradient across the nitracline increased from F1 (81 \pm $\left.49 \mu \mathrm{mol} \mathrm{m} \mathrm{m}^{-4}\right)$ to $\mathrm{F} 2\left(94 \pm 31 \mu \mathrm{mol} \mathrm{m} \mathrm{m}^{-4}\right)$ and F3 (124 $\left.\pm 4 \mu \mathrm{mol} \mathrm{m} \mathrm{m}^{-4}\right)$, although these differences were not statistically significant as a consequence of the large within-cruise variability. The result of these 2 patterns was that vertical fluxes of nitrate were higher during F1 $\left(23 \pm 35 \mathrm{mmol} \mathrm{m} \mathrm{m}^{-2}\right)$ compared to F2 $\left(0.4 \pm 0.2 \mathrm{mmol} \mathrm{m} \mathrm{m}^{-2} \mathrm{~d}^{-1}\right)$ and F3 (0.09 $\left.\pm 0.09 \mathrm{mmol} \mathrm{m} \mathrm{m}^{-2} \mathrm{~d}^{-1}\right)$ (Table 2).

No statistically significant relationships were observed between nitrate supply and the depth-integrated abundances of LNA and HNA bacteria, or Synechococ-
Table 3. Squared Pearson correlation coefficients $\left(r^{2}\right)$ for photic layer depth-integrated abundance, averaged cell volume in the photic layer, vertical diffusive flux of nitrate and light availability in the photic layer (LA) calculated for the FAMOSO cruises. LNA and HNA: low and high nucleic acid content bacteria, respectively; S_picoEuk: small picoeukaryotes; L_picoEuk: large picoeukaryotes. ${ }^{*} p<0.05 ;{ }^{* *} p<0.01 ;{ }^{* * *} p<0.001$. For simplicity, only statistically significant relationships are shown. Variables that did not follow normal distributions were log-transformed

\begin{tabular}{|lccc|}
\hline & $\begin{array}{c}\text { Log bio- } \\
\text { volume }\left(\mathrm{r}^{2}\right)\end{array}$ & $\begin{array}{c}\text { Log nitrate } \\
\text { flux }\left(\mathrm{r}^{2}\right)\end{array}$ & $\begin{array}{c}\text { LA } \\
\left(\mathrm{r}^{2}\right)\end{array}$ \\
\hline Log abundance LNA & & & \\
Log abundance HNA & & & \\
Log abundance Prochlorococcus & $0.903^{* * *}$ & $-0.726^{* *}$ & \\
Log abundance Synechococcus & & & $0.357^{* * *}$ \\
Log abundance S_picoEuk & $-0.584^{* * *}$ & $0.686^{* * *}$ & \\
Log abundance L_picoEuk & & $0.254^{* *}$ & $0.226^{*}$ \\
Cell volume LNA & & $0.287^{*}$ & \\
Cell volume HNA & & $-0.507^{* * *}$ & \\
Log cell volume Prochlorococcus & & $-0.799^{* *}$ & \\
Log cell volume Synechococcus & & $-0.372^{* *}$ & \\
Log cell volume S_picoEuk & & $-0.526^{* * *}$ & \\
Log cell volume L_picoEuk & & & \\
\hline
\end{tabular}
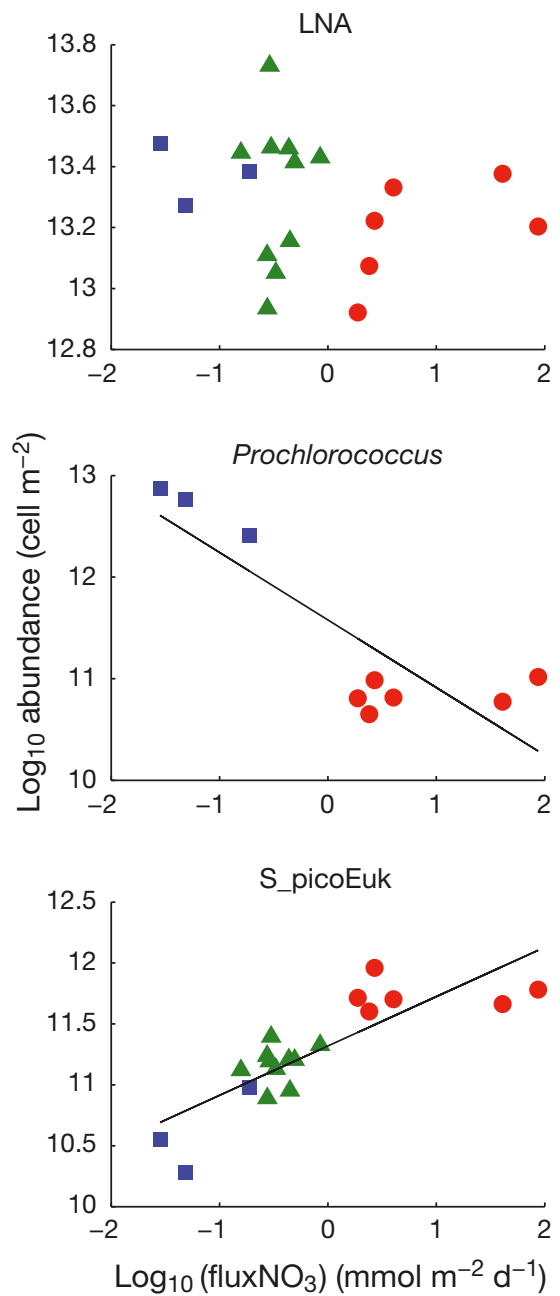
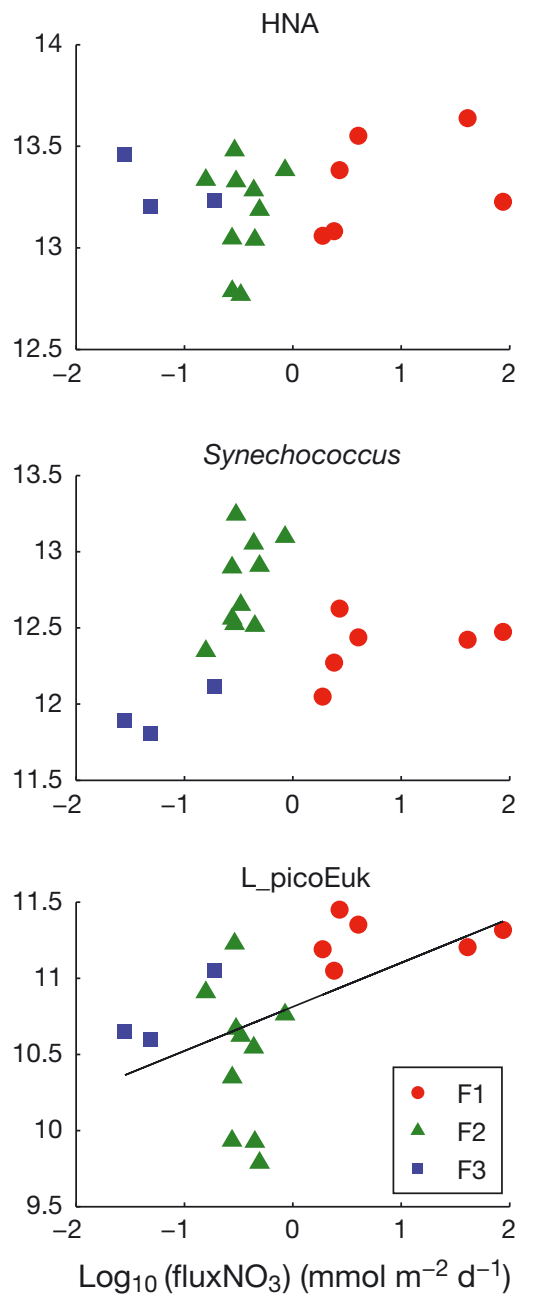

cus, which was higher at intermediate levels of nitrate supply during F2 (Table 3, Fig. 7). Prochlorococcus abundance was negatively correlated with nutrient supply $\left(\mathrm{r}^{2}=-0.726, \mathrm{p}<0.01\right)$, whereas small $\left(\mathrm{r}^{2}=0.686, \mathrm{p}<0.001\right)$ and large $\left(\mathrm{r}^{2}=0.254, \mathrm{p}<0.05\right)$ picoeukaryotes exhibited a significant positive relationship. Nutrient supply showed a positive relationship with the cell size of LNA bacteria, but a negative correlation with that of HNA bacteria, Prochlorococcus, Synechococcus and small picoeukaryotes (Table 3).

In order to summarize our results within the framework of

Fig. 7. Relationship between abundance of low (LNA) and high (HNA) nucleic acid content bacteria, Prochlorococcus, Synechococcus, small picoeukaryotes and large picoeukaryotes and vertical diffusive flux of nitrate computed for the FAMOSO cruises F1, F2 and F3. Black lines: lineal fit for those relationships that were statistically significant, using the total data collected during the 3 cruises (see Table 3 ). Variables that did not follow normal distributions were log-transformed 
the model proposed by the Margalef Mandala, we plotted the dominance of each picophytoplankton group to total autotrophic picoplankton biomass versus vertical diffusivity, surface nitrate concentration and the vertical flux of nitrate through turbulent diffusion (Fig. 8A). This indicates that Prochlorococcus dominated the biomass when nitrate supply
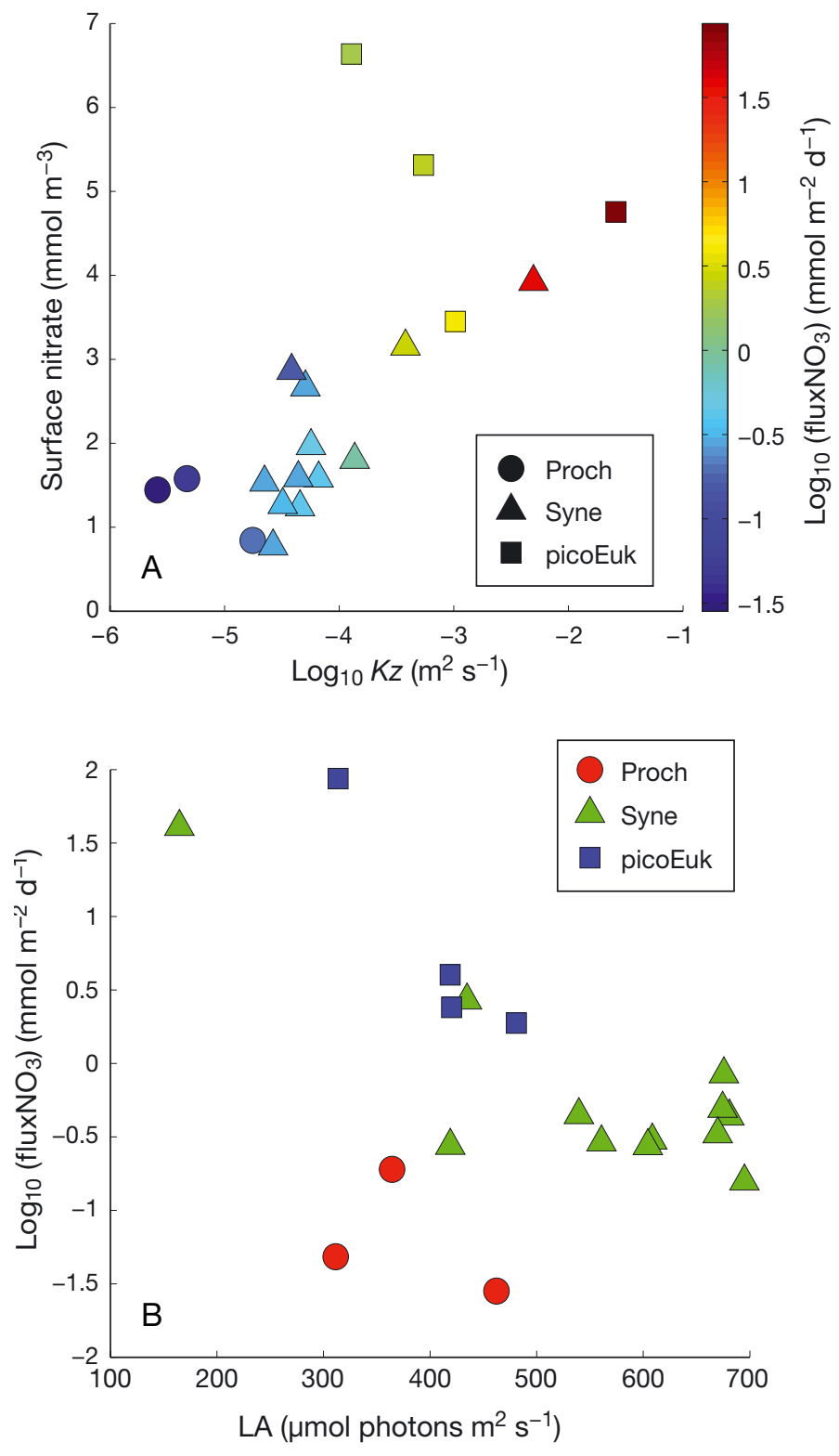

Fig. 8. Dominance (i.e. the group representing the major contribution to total autotrophic picoplankton biomass) of Prochlorococcus (circles), Synechococcus (triangles) or picoeukaryotes (large and small sizes, squares) versus (A) vertical diffusivity, surface nitrate concentration and vertical flux of nitrate through turbulent diffusion (color bar), and (B) light availability in the photic layer (LA) and vertical flux of nitrate through turbulent diffusion computed for the FAMOSO cruises was low, Synechococcus was dominant at intermediate levels of nitrate supply, and both picoeukaryotic groups dominated the biomass under high nutrient supply conditions. As a result of these relationships, the ratio of prokaryotic to picoeukaryotic photoautotrophic biomass decreased with nitrate supply (Fig. 9B).
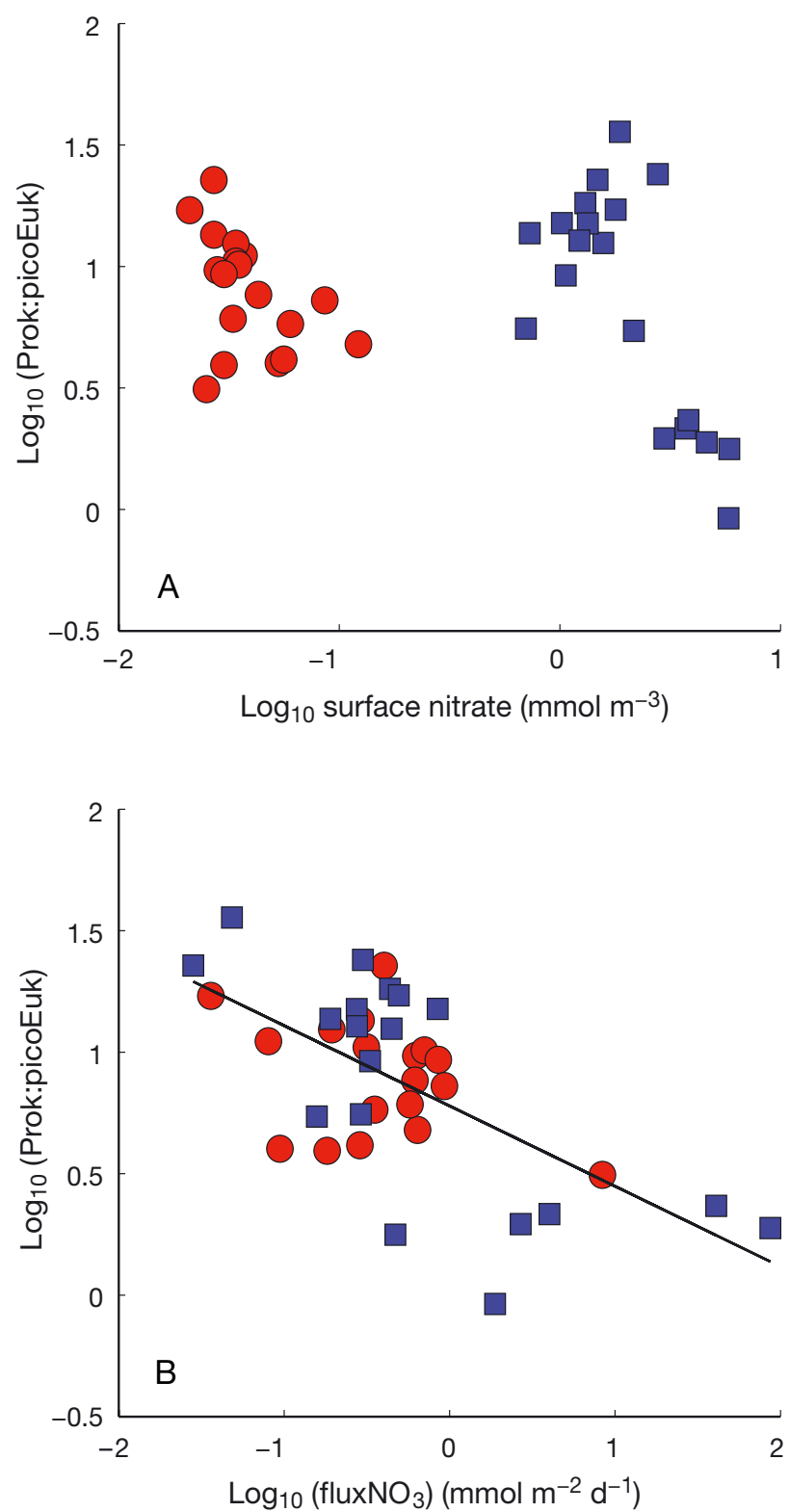

Fig. 9. Ratio of prokaryote to small picoeukaryote photic layer depth-integrated biomass versus (A) nitrate concentration and (B) vertical diffusive flux of nitrate during the FAMOSO (blue squares) and the TRYNITROP (red circles, tropical and subtropical Atlantic) cruises. Black line: statistically significant relationship $\left(\mathrm{r}^{2}=0.395 ; \mathrm{p}<0.001\right)$ calculated using data from both the FAMOSO and the TRYNITROP cruises 


\section{DISCUSSION}

\section{Control of nutrient supply on picoplankton}

Our results clearly show that the model proposed by Margalef (1978) can also be applied to picophytoplankton in the Mediterranean Sea, as the different autotrophic picoplankton types dominated along a gradient in turbulence and nitrate supply in a manner consistent with the larger organisms considered by Margalef (Fig. 8A). These results point to different resource requirements of the picophytoplankton groups that are consistent with differential use of new and regenerated forms of nitrogen. Prochlorococcus growth has traditionally been considered to be based mainly on regenerated forms of nitrogen (Moore et al. 2001, 2007), though they are also known to assimilate nitrate (Casey et al. 2007, Martiny et al. 2009, Treibergs et al. 2014). Synechococcus are able to use a large diversity of new and regenerated forms of nitrogen, including nitrate, nitrite, ammonium, urea and amino acids (Glibert et al. 1986, Moore et al. 2001, Wawrik et al. 2009). They can even degrade their own phycoerythrin to use as an internal nitrogen source under extreme nitrogendepleted conditions (Wyman et al. 1985). Eukaryotic phytoplankton can use all forms of fixed nitrogen, as well as amino acids and urea (Mulholland \& Lomas 2008). A recent study carried out in the Sargasso Sea, combining flow cytometry and isotopic composition, supports the view that prokaryotes rely on recycled nitrogen, whereas small eukaryotes obtain most of their nitrogen demand from upwelled nitrate (Fawcett et al. 2011). Moreover, pigment markers confirm the trophic preferences presented here, as Prochlorococcus are associated with the most oligotrophic conditions, while Synechococcus and picoeukaryotes are associated with mesotrophic conditions (Latasa et al. 2010).

Our results showing the different responses of picophytoplankton groups to nitrate supply also support the notion that, due to differences in cell size, picophytoplankton groups have different nutrient uptake capabilities at different nutrient levels. Because smaller cell sizes lead to an increase in nutrient diffusion per unit of cell volume and a thinning of the diffusion boundary layer around the cell, smaller sizes have a competitive advantage when nutrient availability is low (Chisholm 1992, Kiørboe 1993, Raven 1998). Recent field and laboratory studies indicate that growth rates are similar in both small and large cells, but peak at intermediate cell sizes as the result of trade-off processes related to nutrient requirements, acquisition and use (Marañón et al. 2014, Marañón 2015). Due to their very small size, Prochlorococcus cells are better prepared to cope with extremely low nutrient supply conditions, whereas Synechococcus and picoeukaryotes tend to dominate in nitrate-rich waters due to their faster growth rates at elevated nitrate concentrations. The negative relationship observed between cell size and nutrient supply for Prochlorococcus, Synechococcus and small picoeukaryotes (see Table 3) could have a physiological explanation. Previous studies have shown that nutrient starvation can limit the division of cells, and that under these conditions an increase in cell size occurs (Latasa \& Berdalet 1994). The significant negative relationship found in our data between cell size and abundance of small picoeukaryotes (Table 3 ) is in agreement with this mechanism.

The lack of a significant relationship between the abundance of LNA and HNA bacteria and nutrient supply (Fig. 7, Table 3) contradicts the view that bacterial activity is directly controlled by inorganic nutrient inputs (Kirchman 2000). However, the lack of a statistical relationship in our data may have resulted from a relatively narrow range of trophic conditions during our study. Despite finding no indication of the role of nutrient supply on HNA and LNA bacteria, we cannot rule out that potential relationships would appear if bacterial growth, instead of bacterial abundance, was used to study the response of bacterial communities.

\section{The use of proxies for estimating nutrient supply}

For the first time, we used observations of microturbulence in the ocean in order to investigate the influence of mixing and nutrient supply dynamics on picoplankton community structure, in the context of Margalef's Mandala. Due to the difficulties involved with measuring turbulence in the field, previous studies utilized different proxies for nutrient supply, and very often used the terms mixing and stratification interchangeably. Li (2002) showed that as stratification decreases in the North Atlantic there is an increase in large nanoplankton (10 to $20 \mu \mathrm{m}$ diameter), a decrease in picoplankton, and no apparent variation in small nanoplankton, which constitutes the uniform background. Bouman et al. (2011) used stratification as a proxy accounting for the 3 main environmental factors governing phytoplankton growth in the sea: temperature, light and nutrients. By analyzing data from the subtropical Pacific, 
Indian and Atlantic oceans, they observed that picoeukaryotes dominate in well-mixed waters, whereas Prochlorococcus are prevalent in strongly stratified regions. Similar patterns were described by Corno et al. (2007), who used lower euphotic zone stratification to describe patterns in the composition of the picoplankton community at the ALOHA time-series station. As far as we know, previous studies that focused on the relationship between bacterial abundance and nutrient supply are limited to the study by Gasol et al. (2009), who described a positive relationship between water column stratification and heterotrophic bacterial abundance.

Except for heterotrophic picoplankton, our work is generally consistent with previous studies. However, in these previous studies the relationship between picoplankton abundance and nutrient supply was not obvious, since stratification and mixing are not equivalent, neither from a physical perspective nor in their effects on phytoplankton. Vertical diffusivity or mixing refers to the homogenization of gradients of a property. It can be regarded as the trade-off between the kinetic, and sometimes potential, energy available to drive the turbulence, and the density stratification that can suppress it (Franks 2015). In the field, turbulence is usually measured in terms of the dissipation rate of turbulent kinetic energy, with large values indicating that there is a large amount of kinetic energy from turbulence being dissipated at small scales.

During the FAMOSO cruises, and probably in other studies comparing highly contrasting hydrographic regimes, stratification could be a valid proxy for mixing and nutrient supply, as intense stratification conditions are associated with low dissipation rates, low mixing and low nutrient supply (see Table 2). However, increases in turbulence and mixing can also occur in stratified water columns due to, for example, internal wave generation, whose activity and propagation increases with the stratification (Baines 1982). At the shelf edge of the North Sea (Sharples et al. 2007) and the outer part of the Ría de Vigo (Villamaña-Rodríguez et al. 2015), high levels of dissipation rates of turbulent kinetic energy have been described within the stratified pycnocline associated with the breaking internal tide during the spring tides.

The notion that 2 factors, turbulent mixing and nutrient concentration, determine the magnitude of the nutrient supply was included in the first diagram proposed by Margalef (1978), who chose surface nutrient concentration as the variable representing nutrient availability. From a recent analysis of all major ocean regions, Flombaum et al. (2013) concluded that temperature and light are the main factors controlling Prochlorococcus and Synechococcus distributions, whereas they could not find a clear relationship between nutrient concentration (used in that study as a proxy for nutrient supply) and cell abundance. However, particularly in tropical and subtropical regions, the variability in nutrient supply into the surface waters can be disconnected from changes in nutrient concentrations (Mouriño-Carballido et al. 2011). Our results show different responses of picophytoplankton groups to nitrate supply, and as a result of these relationships, the ratio of prokaryotic to picoeukaryotic photoautotrophic biomass decreased with increasing nitrate supply (Fig. 9). However, in this case it is of no consequence if nitrate concentration or nitrate diffusive fluxes are used, as both variables were correlated during the FAMOSO cruises $\left(\mathrm{r}^{2}=0.492 ; \mathrm{p}<0.001\right)$. In order to determine whether our results could apply to regions in which surface nitrate concentration and nitrate diffusive fluxes are clearly disconnected (Mouriño-Carballido et al. 2011), we included data collected in the tropical and subtropical Atlantic during the TRYNITROP cruise (Fig. 9). Results from this analysis indicated that the observed relationship between nitrate supply and the prokaryotic to picoeukaryotic biomass ratio during the FAMOSO cruises is also valid for the tropical and subtropical Atlantic, but that this relationship only appears when nutrient fluxes, and not surface nutrient concentration, are used as a proxy for nutrient supply.

\section{Role of additional factors}

Our analysis of the model proposed by Margalef (1978) has focused so far on the role that nutrient supply plays in determining picoplankton community structure. The model proposed by Margalef is a simplified bottom-up control model explicitly including only 2 environmental factors (inorganic macronutrients and turbulent mixing), placed orthogonally in the diagram (although the 2 axes are not technically independent). The use of these 2 variables accommodates the view that, given the scarcity of nutrients and the dissipative effects of turbulent mixing, the pelagic habitat is generally hostile to phytoplankton growth. For this reason, the inputs of external energy, on which advection and turbulent mixing depend, control the prominent lifeforms of phytoplankton. Although not represented in the original diagram, other environmental factors such as grazing and light 
availability were discussed by Margalef and are implicitly included in the model. Maximum predator-prey encounter rates occur at an optimum value of turbulent mixing (Lasker 1975), whilst phytoplankton biomass accumulates as grazing pressure lags behind the growth rate of large cells (Kiørboe 1993). The transport of cells through the vertical light gradient also depends on mixing (Vallina \& Simó 2007). Light availability was included explicitly in a model proposed by Reynolds (1987), known as the Reynolds's Intaglio, which predicts the composition of phytoplankton along a gradient of environmental factors (light, nutrients and mixing) (e.g. Smayda \& Reynolds 2001). The Intaglio refined Margalef's axes: the turbulence axis was replaced by a vector reflecting light availability, which considered the vertical extent of the mixing, light intensity and its attenuation with depth, whereas the nutrient axis became the accessibility of this resource. The vertical extent of mixing is often represented as the mixed layer depth, typically defined as the shallowest depth at which a difference in temperature or density, measured from the surface, reaches a given threshold (Kara et al. 2000). However, this layer does not necessarily mean a mixing layer, where waters are kept in motion through turbulence (Franks 2015).

Modifying the expression proposed by Vallina \& Simó (2007) for solar radiation dose, we calculated a proxy for light availability in the photic layer (i.e. LA), taking into consideration the magnitude of the surface radiation, the light attenuation coefficient, and the vertical displacements due to turbulent diffusivity (see 'Materials and methods'). The correlation analysis between LA and picoplankton abundance showed that only large picoeukaryotes $\left(\mathrm{r}^{2}=0.226\right.$, $\mathrm{p}<0.05)$ and Synechococcus $\left(\mathrm{r}^{2}=0.357, \mathrm{p}<0.001\right)$, the latter being the only autotrophic picoplankton group which did not correlate significantly with nutrient supply, showed a significant positive relationship with light availability (Table 3). Hence, in our case light availability appears to play a more important role than nutrients in controlling the higher Synechococcus abundances sampled during F2 (Fig. 8B).

We are aware that more data, covering a larger spectrum of hydrographical conditions, would be required in order to determine the relative contribution of the availability of light and nutrients in structuring picoplankton community composition. However, our results indicate that nutrient supply was more important than light availability as a factor responsible for the overall picoplankton composition observed during the FAMOSO cruises in the northwestern Mediterranean Sea (Fig. 8).

\section{Outlook}

Autotrophic and heterotrophic picoplankton dominate numerically as well as in terms of biomass within oligotrophic, highly-stratified regions such as the subtropical gyres, which could be expanding as a result of global warming (Polovina et al. 2008). It is believed that in these regions, the fate of carbon fixed in the upper layer depends on the composition of picophytoplankton groups (i.e. the ratio of prokaryotes: eukaryotes) (Corno et al. 2007). However, our limited understanding about the factors that control picoplankton composition constrains our ability to include them in ocean biogeochemical models, and to predict the consequences of future global change scenarios. For the first time, by using observations in the ocean, we directly investigated the influence of mixing and nutrient supply dynamics on picoplankton community structure in the context of the Margalef model. Our results indicate that, in agreement with Margalef's work, picophytoplankton groups exhibit different behaviours in response to nitrate supply and, as a result of this relationship, the ratio of prokaryotic to picoeukaryotic biomass decreases with increasing nitrate supply. The observed relationship between nitrate supply and the ratio of prokaryote to picoeukaryote biomass during the FAMOSO cruises is also valid for the tropical and subtropical Atlantic, where surface nitrate concentration and nitrate diffusive fluxes are clearly disconnected. Moreover, in these oligotrophic domains the role of nutrients is only apparent when nitrate diffusive fluxes, and not nutrient concentrations, are used. We are aware that our approach ignores other mechanisms that are potentially important for new nitrogen supply in these regions, such as mesoscale and sub-mesoscale turbulence, lateral transport, atmospheric deposition, nitrogen fixation and more complex 3-dimensional dynamics (Jenkins \& Doney 2003, Bonnet \& Chiaverini 2005, Bonnet et al. 2011, Estrada et al. 2014).

Accurate estimates of nutrient supply are crucial to discern the role that environmental factors play in the composition of picophytoplankton. The utilization of microstructure profilers resolves the old methodological limitations of obtaining accurate estimates of diffusivity, which are needed to compute the transport of nutrients through the thermocline. They also open up a new field of possibilities to obtain a better understanding of the connection between hydrographic heterogeneities at the marine microscale and the diversity, activity and biogeochemistry of microbial communities (Stocker 2012, Taylor \& Stocker 2012). 
Acknowledgements. We thank the crew and colleagues onboard the RVs 'Sarmiento de Gamboa' and 'Hespérides' for their support during the cruises, and M. Estrada for providing helpful comments on the manuscript. We are very grateful to the detailed comments provided 3 anonymous reviewers and the editor during the revision process. This work was funded by the Spanish projects TRYNITROP (CTM2004-05174-C02), FAMOSO (CTM2008-06261-C03), TURBIMOC (CTM2009-06712-E/MAR), and CHAOS (CTM 2012-30680). P.C. was supported by a Ramon y Cajal fellowship. B.F.-C. thanks the Spanish Government for support through a FPU fellowship (AP2010-5594).

\section{LITERATURE CITED}

Baines PG (1982) On internal tide generation models. DeepSea Res A 29:307-338

$>$ Bonnet S, Chiaverini J (2005) Effect of atmospheric nutrients on the autotrophic communities in a low nutrient, low chlorophyll system. Limnol Oceanogr 50:1810-1819

> Bonnet S, Grosso O, Moutin T (2011) Planktonic dinitrogen fixation along a longitudinal gradient across the Mediterranean Sea during the stratified period (BOUM cruise). Biogeosciences 8:2257-2267

- Bouman HA, Ulloa O, Barlow R, Li WKW and others (2011) Water-column stratification governs the community structure of subtropical marine picophytoplankton. Environ Microbiol Rep 3:473-482

Bouvier T, del Giorgio PA, Gasol JM (2007) A comparative study of the cytometric characteristics of high and low nucleic-acid bacterioplankton cells from different aquatic ecosystems. Environ Microbiol 9:2050-2066

> Calvo-Díaz A, Morán XAG (2006) Seasonal dynamics of picoplankton in shelf waters of the southern Bay of Biscay. Aquat Microb Ecol 42:159-174

> Calvo-Díaz A, Díaz-Pérez L, Suárez LÁ, Morán XAG, Teira E, Marañón E (2011) Decrease in the autotrophic-toheterotrophic biomass ratio of picoplankton in oligotrophic marine waters due to bottle enclosure. Appl Environ Microbiol 77:5739-5746

> Casey JR, Lomas MW, Mandecki J, Walker DE (2007) Prochlorococcus contributes to new production in the Sargasso Sea deep chlorophyll maximum. Geophys Res Lett 34, L10604, doi:10.1029/2006GL028725

Chisholm SW (1992) Phytoplankton size. In: Falkowski P, Woodhead A (eds) Primary productivity and biogeochemical cycles in the sea. Plenum Press, New York, NY, p 213-237

Chisholm SW, Olson RJ, Zettler ER, Goericke R, Waterbury JB, Welschmeyer NA (1988) A novel free-living prochlorophyte abundant in the oceanic euphotic zone. Nature 334:340-343

Corno G, Karl DM, Church MJ, Letelier RM, Lukas R, Bidigare RR, Abbott MR (2007) Impact of climate forcing on ecosystem processes in the North Pacific Subtropical Gyre. J Geophys Res 112, C04021, doi:10.1029/2006JC 003730

Estrada M (1996) Primary production in the northwestern Mediterranean. Sci Mar 60:55-64

Estrada M, Latasa M, Emelianov M, Gutiérrez-Rodríguez A and others (2014) Seasonal and mesoscale variability of primary production in the deep winter-mixing region of the NW Mediterranean. Deep-Sea Res I 94:45-61

$>$ Fawcett SE, Lomas M, Casey JR, Ward BB, Sigman DM
(2011) Assimilation of upwelled nitrate by small eukaryotes in the Sargasso Sea. Nat Geosci 4:717-722

Fernández-Castro B, Mouriño-Carballido B, Marañón E, Chouciño P and others (2015) Importance of salt fingering for new nitrogen supply in the oligotrophic ocean. Nat Commun 6:8002

> Flombaum P, Gallegos JL, Gordillo RA, Rincón J, Zabala LL, Jiao N (2013) Present and future global distributions of the marine Cyanobacteria Prochlorococcus and Synechococcus. Proc Natl Acad Sci USA 110:9824-9829

Franks P (2015) Has Sverdrup's critical depth hypothesis been tested? Mixed layers vs. turbulent layers. ICES J Mar Sci 72:1897-1907

> Gasol JM, Vázquez-Domínguez E, Vaqué D, Agustí S, Duarte CM (2009) Bacterial activity and diffusive nutrient supply in the oligotrophic central Atlantic Ocean. Aquat Microb Ecol 56:1-12

> Gasol JM, Zweifel UL, Peters F, Fuhrman JA, Hagstrom A (1999) Significance of size and nucleic acid content heterogeneity as measured by flow cytometry in natural planktonic bacteria. Appl Environ Microbiol 65:4475-4483

Glibert PM, Kana TM, Olson RJ, Kirchman DL, Alberte RS (1986) Clonal comparisons of growth and photosynthetic responses to nitrogen availability in marine Synechococcus spp. J Exp Mar Biol Ecol 101:199-208

Gomes A, Gasol JM, Estrada M, Franco-Vidal L, Díaz-Pérez L, Ferrera I, Morán XAG (2015) Heterotrophic bacterial responses to the winter-spring phytoplankton bloom in open waters of the NW Mediterranean. Deep-Sea Res I 96:59-68

Grasshoff K, Kremling K, Ehrhardt M (eds) (1999) Methods of seawater analysis, 3rd edn. Wiley-VCH Verlag, Weinheim

Gregg MC, Alford MH, Kontoyiannis H, Zervakis V, Winkel D (2012) Mixing over the steep side of the Cycladic Plateau in the Aegean Sea. J Mar Syst 89:30-47

Jenkins WJ, Doney SC (2003) The subtropical nutrient spiral. Global Biogeochem Cycles 17:1110, doi:10.1029/ 2003GB002085

Johnson ZI, Zinser ER, Coe A, McNulty NP, Woodward EMS, Chisholm SW (2006) Niche partitioning among Prochlorococcus ecotypes along ocean-scale environmental gradients. Science 311:1737-1740

Kara AB, Rochford PA, Hurlburt HE (2000) An optimal definition for ocean mixed layer depth. J Geophys Res 105(C7):16803-16821

Kiørboe T (1993) Turbulence, phytoplankton cell size, and the structure of pelagic food webs. Adv Mar Biol 29:1-72

Kirchman DL (2000) Uptake and regeneration of inorganic nutrients by marine heterotrophic bacteria. In: Kirchman DL (ed) Microbial ecology of the oceans. John Wiley \& Sons, New York, NY, p 261-288

Kirk JTO (1994) Light and photosynthesis in aquatic ecosystems, 2nd edn. Cambridge University Press, Cambridge

Lasker R (1975) Field criteria for survival of anchovy larvae: the relation between inshore chlorophyll maximum layers and successful first feeding. Fish Bull 73:453-462

Latasa M, Berdalet E (1994) Effect of nitrogen or phosphorus starvation on pigment composition of cultured Heterocaspa sp. J Plankton Res 16:83-94

- Latasa M, Scharek R, Vidal M, Vila-Reixach G, GutiérrezRodríguez A, Emelianov M, Gasol JM (2010) Preferences of phytoplankton groups for waters of different trophic status in the northwestern Mediterranean Sea. Mar Ecol Prog Ser 407:27-42 
Leaman KD, Schott F (1991) Hydrography structure of the convection regime in the Gulf of Lions: winter 1987. J Phys Oceanogr 21:575-598

Ledwell JR, Montgomery ET, Polzin KL, St. Laurent LC, Schmitt RW, Tooole JM (2000) Evidence for enhanced mixing over rough topography in the abyssal ocean. Nature 403:179-182

Li WKW (2002) Macroecological patterns of phytoplankton in the northwestern North Atlantic Ocean. Nature 419: $154-157$

Li WKW (2007) Macroscopic patterns in marine plankton. In: Levin SA (ed) Encyclopedia of biodiversity. Elsevier, Amsterdam, p 1-16

Litchman E (2007) Resource competition and ecological success of phytoplankton. In: Falkowski PG, Knoll AH (eds) Evolution of primary producers in the sea. Elsevier, London, p 351-375

Longnecker K, Sherr BF, Sherr EB (2005) Activity and phylogenetic diversity of bacterial cells with high and low nucleic acid content and electron transport system activity in an upwelling ecosystem. Appl Environ Microbiol 71:7737-7749

MacArthur RH, Wilson EO (1967) The theory of island biogeography. Princeton University Press, Princeton, NJ

Marañón E (2015) Cell size as a key determinant of phytoplankton metabolism and community structure. Ann Rev Mar Sci 7:241-264

- Marañón E, Cermeño P, Huete-Ortega M, López-Sandoval DC, Mouriño-Carballido B, Rodríguez-Ramos T (2014) Resource supply overrides temperature as a controlling factor of marine phytoplankton growth. PLoS ONE 9: e99312

Margalef R (1978) Life-forms of phytoplankton as survival alternatives in an unstable environment. Oceanol Acta 1: 493-509

Margalef R, Estrada M, Blasco D (1979) Functional morphology of organisms involved in red tides, as adapted to decaying turbulence. In: Taylor DL, Seliger $\mathrm{HH}$ (eds) Toxic dinoflagellate blooms. Elsevier-North Holland, Amsterdam, p 89-94

Marie D, Partensky F, Vaulot D (1999) Enumeration of phytoplankton, bacteria, and viruses in marine samples. Curr Protoc Cytom 10:11.11.1-11.11.15

Martiny AC, Kathuria S, Berube PM (2009) Widespread metabolic potential for nitrite and nitrate assimilation among Prochlorococcus ecotypes. Proc Natl Acad Sci USA 106:10787-10792

> McCree KT (1972) The action spectrum, absorptance and quantum yield of photosynthesis in crop plants. Agric Meteorol 9:191-216

- Moore JK, Doney SC, Glover DM, Fung IY (2001) Iron cycling and nutrient-limitation patterns in surface waters of the World Ocean. Deep-Sea Res II 49:463-507

Moore LR, Coe A, Zinser ER, Saito MA and others (2007) Culturing the marine cyanobacterium Prochlorococcus. Limnol Oceanogr 5:353-362

Morán XAG, Estrada M (2005) Winter pelagic photosynthesis in the NW Mediterranean. Deep-Sea Res I 52: 1806-1822

Morán XAG, Ducklow HW, Erickson M (2011) Single-cell physiological structure and growth rates of heterotrophic bacteria in a temperate estuary (Waquoit Bay, Massachusetts). Limnol Oceanogr 56:37-48

Moum JN, Smyth WD (2001) Upper ocean mixing. Encycl Ocean Sci 6:3093-3100
Mouriño-Carballido B, Graña R, Fernández A, Bode A and others (2011) Importance of $\mathrm{N}_{2}$ fixation vs. nitrate eddy diffusion along a latitudinal transect in the Atlantic Ocean. Limnol Oceanogr 56:999-1007

Mulholland MR, Lomas MW (2008) Nitrogen uptake and assimilation. In: Capone DG, Bronk DA, Mulholland MR, Carpenter EJ (eds) Nitrogen in the marine environment, 2nd edn. Elsevier, Amsterdam, p 303-384

Norland S (1993) The relationship between biomass and volume of bacteria. In: Kemp P, Sherr B, Sherr E, Cole J (eds) Handbook of methods in aquatic microbial biology. Lewis Publishers, Boca Raton, FL, p 303-307

- Oakey NS, Greenan BJW (2004) Mixing in a coastal environment: 2. A view from microstructure measurements. J Geophys Res 109:C10014, doi:10.1029/2003JC002193

Osborn TR (1980) Estimates of the local rate of vertical diffusion from dissipation measurements. J Phys Oceanogr 10:83-89

Partensky F, Blanchot J, Vaulot D (1999a) Differential distribution and ecology of Prochlorococcus and Synechococcus in oceanic waters: a review. Bull Inst Oceanogr 19: $457-475$

> Partensky F, Hess WR, Vaulot D (1999b) Prochlorococcus, a marine photosynthetic prokaryote of global significance. Microbiol Mol Biol Rev 63:106-127

Pianka ER (1970) On $r$ - and $K$-Selection. Am Nat 104: 592-597

Polovina JJ, Howell EA, Abecassis M (2008) Ocean's least productive waters are expanding. Geophys Res Lett 35: L03618, doi:10.1029/2007GL031745

Prandke H, Stips A (1998) Test measurements with an operational microstructure-turbulence profiler: detection limit of dissipation rates. Aquat Sci 60:191-209

Raven JA (1998) The twelfth Tansley lecture. Small is beautiful: the picophytoplankton. Funct Ecol 12:503-513

Reynolds CS (1987) Community organization in the freshwater plankton. In: Gee JHR, Giller PS (eds) Organization of communities, past and present. Wiley-Blackwell, Oxford, p 297-325

> Richardson TL, Jackson GA (2007) Small phytoplankton and carbon export from the surface ocean. Science 315: 838-840

> Scharek R, Latasa M (2007) Growth, grazing and carbon flux of high and low nucleic acid bacteria differ in surface and deep chlorophyll maximum layers in the NW Mediterranean Sea. Aquat Microb Ecol 46:153-161

- Schattenhofer M, Fuchs BM, Amann R, Zubkov MV, Tarran GA, Pernthaler J (2009) Latitudinal distribution of prokaryotic picoplankton populations in the Atlantic Ocean. Environ Microbiol 11:2078-2093

Sharples J, Moore CM, Rippeth TP, Holligan PM, Hydes DJ, Fisher NR, Simpson JH (2001) Phytoplankton distribution and survival in the thermocline. Limnol Oceanogr 46:486-496

> Sharples J, Tweddle JF, Green JAM, Palmer MR and others (2007) Spring-neap modulation of internal tide mixing and vertical nitrate fluxes at a shelf edge in summer. Limnol Oceanogr 52:1735-1747

Sharples J, Moore CM, Hickman AE, Holligan PM, Tweddle JF, Palmer MR, Simpson JH (2009) Internal tidal mixing as a control on continental margin ecosystems. Geophys Res Lett 36:L23603, doi:10.1029/2009GL040683

> Smayda TJ, Reynolds CS (2001) Community assembly in marine phytoplankton: application of recent models to harmful dinoflagellate blooms. J Plankton Res 23:447-461 
Stocker R (2012) Marine microbes see a sea of gradients. Science 338:628-633

Tarran GA, Heywood JL, Zubkov MV (2006) Latitudinal changes in the standing stocks of nano- and picoeukaryotic phytoplankton in the Atlantic Ocean. Deep-Sea Res II 53:1516-1529

Taylor JR, Stocker R (2012) Trade-offs of chemotactic foraging in turbulent water. Science 338:675-679

Thorpe SA (2007) An introduction to ocean turbulence. Cambridge University Press, Cambridge

Treibergs LA, Fawcett SE, Lomas MW, Sigman DM (2014) Nitrogen isotopic response of prokaryotic and eukaryotic phytoplankton to nitrate availability in Sargasso Sea surface waters. Limnol Oceanogr 59:972-985

> Vallina SM, Simó R (2007) Strong relationship between DMS and the solar radiation dose over the global surface ocean. Science 315:506-508

Villamaña-Rodríguez M, Mouriño-Carballido B, Cermeño P,

Editorial responsibility: Graham Savidge,

Portaferry, UK
Choucino P and others (2015) Role of internal waves on mixing, nutrient supply and phytoplankton composition during spring and neap tides in the Ría de Vigo (NW Iberian Peninsula). ASLO Aquatic Science Meeting, 22-27 February 2015, Granada (Abstract)

Wawrik B, Callaghan AV, Bronk DA (2009) Use of inorganic and organic nitrogen by Synechococcus spp. and diatoms on the West Florida Shelf as measured using stable isotope probing. Appl Environ Microbiol 75:6662-6670

Worden AZ, Nolan JK, Palenik B (2004) Assessing the dynamics and ecology of marine picophytoplankton: the importance of the eukaryotic component. Limnol Oceanogr 49:168-179

Wyatt T (2014) Margalef's mandala and phytoplankton bloom strategies. Deep-Sea Res Part II 101:32-49

Wyman M, Gregory RPF, Carr NG (1985) Novel role for phycoerythrin in a marine cyanobacterium, Synechococcus strain DC2. Science 230:818-820

Submitted: October 1, 2014; Accepted: November 18, 2015 Proofs received from author(s): January 11, 2016 